\title{
VALOR NUTRITIVO DA SEMENTE DE MARACUJÁ (Dassiflora edulis, Sims., Forma Flavicarpa, Deuger) PARA RUMINANTES: DIGESTIBILIDADE E NIVEIS NA DIETA
}

\author{
WASHINGTON MATOS MOREIRA
}

Engenhaipo - ăgrônamo

Orientador: Dr. Wilson Roberto S. Mattos

\footnotetext{
Dissertação apresentada à Escola Superior de Agricultura "Luiz de Queiroz", da Universidade de São Paulo, para obtenção do título de Mestre em Nutrição Animal e Pasłagens.
}

$P \mid R A C I C A B A$

Estado de São Paulo - Brasil

Abril, 1980 
À Vilma, minha esposa

Leonardo e Clarissa, meus filhos,

pelas restrições a que se submeteram para tornar possível a conclusão deste empreendimento,

OFEREÇO. 


\section{A GRADECIMEN TOS}

Ao Prof. Dr. Wilson Roberto Soares Mattos pela orientação segura, mas liberal.

Ao Prof. Dr. Irineu Umberto Packer pela orientação relativa aos aspectos estatísticos deste trabalho.

Ao Prof. Dr. Max Lázaro Vieira Bose pela revisão do texto do presente trabalho.

Ao Prof. Dr. Celso Lemaire de Moraes pelas facilidades ofe recidas quando da utilização do Laboratório de Nutrição Animal da ESAIQ.

A Unidade de Execução de Pesquisas de Ambito Estadual de Quissamä, Sergipe, na pessoa do Eng으 Agrọ Jorge do Prado Sobral, pelas prọ vidências para aquisição de parte do material utilizado neste experimento.

Ao Instituto de Zootecnia da Secretaria de Agricultura do Estado de São Paulo, pelo empréstimo dos animais experimentais.

A Empresa Brasileira de Pesquisa Agropecuária (EMBRAPA) pe la oportunidade de treinamento a nível de pós-graduação. 


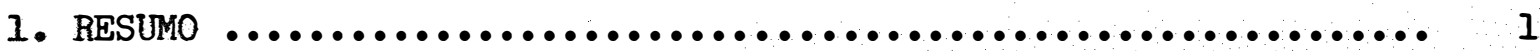

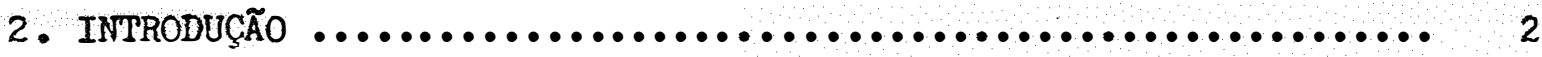

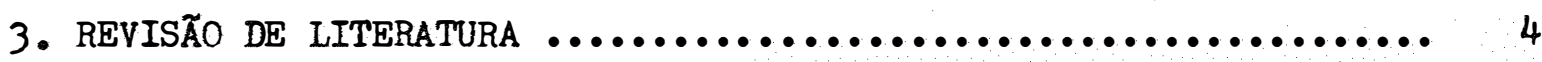

3.1. Semente de maracujá $\ldots \ldots \ldots \ldots \ldots \ldots \ldots \ldots \ldots \ldots \ldots \ldots \ldots, 4$

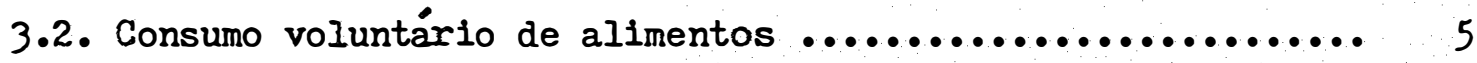

3.3. Alguns fatores relacionados com a digestibilidade ........ 9

3.3.1. Nível de ingestão $\ldots \ldots \ldots \ldots \ldots \ldots \ldots \ldots \ldots \ldots \ldots \ldots \ldots$

3.3.2. Composição do alimento ......................... 12

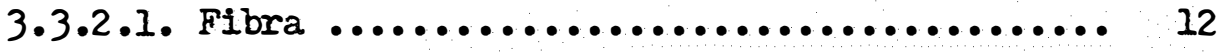

3.3.2.2. Extrativo-não-nitrogenado ............... 16

3.3.2.3. Proteina bruta $\ldots \ldots \ldots \ldots \ldots \ldots \ldots \ldots \ldots . . . \ldots 20$

3.3.2.4. Extrato etéreo $\ldots \ldots \ldots \ldots \ldots \ldots \ldots \ldots \ldots . \ldots . \ldots 23$

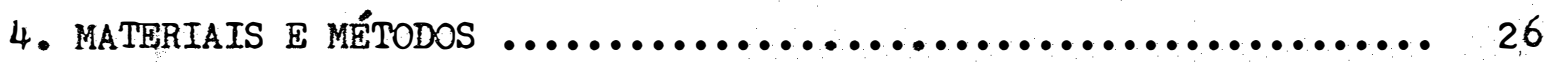

4.1. Tratamentos e delineamento estatístico $\ldots \ldots \ldots \ldots \ldots \ldots \ldots 26$

4.2. Obtenção dos componentes da dieta .................. 28

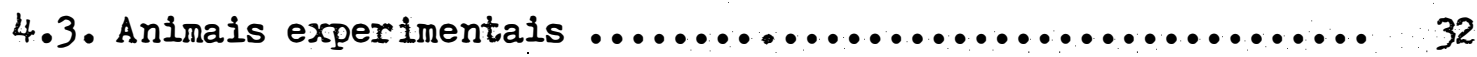

4.4. Alterações durante 0 experimento $\ldots . . . \ldots \ldots \ldots . . . \ldots . . .34$

4.5. Coleta, amostragem e armazenamento de fezes ............ 35

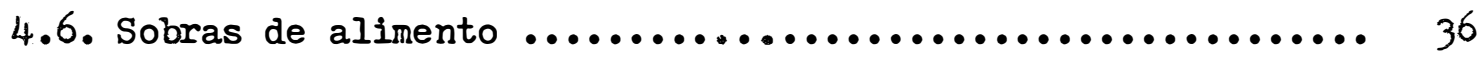

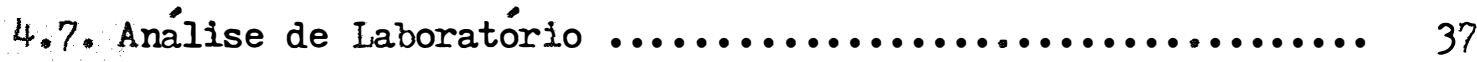


Página

5. RESULTADOS E DISCUSSÃO $\ldots \ldots \ldots \ldots \ldots \ldots \ldots \ldots \ldots \ldots \ldots \ldots \ldots \ldots \ldots \ldots \ldots \ldots \ldots \ldots$

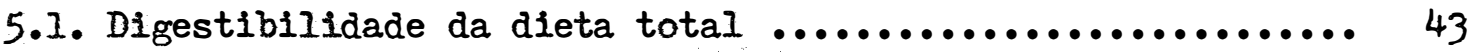

5.2. Digestibilidade da semente de maracujá ................. 4 ?

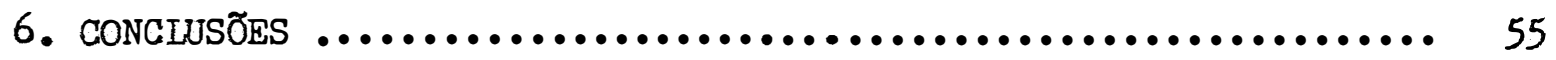

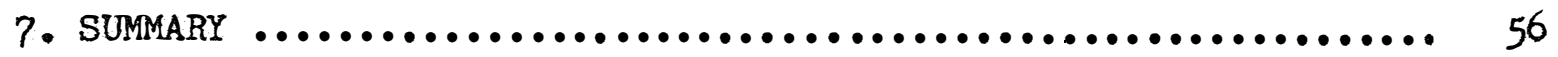

8. LITERATURA CITADA $\ldots \ldots \ldots \ldots \ldots \ldots \ldots \ldots \ldots \ldots \ldots \ldots \ldots \ldots \ldots \ldots \ldots$

9. APÊNDICE 


\section{RESUMO}

Foi estudada a possibilidade de uso da semente de maracujá (Passiflora edulis, sims . forma flavicarpa, Deuger) na alimentação de ruminantes. Oito carneiros adultos foram usados para medir a digestibilidade de quatro rações estabelecidas a partir de uma dieta básica constituida de $700 \mathrm{~g}$ de feno de Rhodes (Chloris gayana) mais $100 \mathrm{~g}$ de torta de algodão, na qual se substituiu zero, 100,200 e $300 \mathrm{~g}$ do feno por semente de maracujá. Mediu-se ainda a digestibilidade desta última, por diferença. A elevação dos níveis de semente de maracujá foi acompanhada, na dieta total, por decréscimo na digestibilidade da matéria seca $(62,6$ para $52,0 \%)$, fibra bruta $(69,1$ para $32,9 \%)$ e extrativo não nitrogenado $(62,6$ para $56,4 \%)$; aumento na digestibilidade da proteina bruta $(64,8$ para $72,3 \%)$ e extrato etéreo $(44,5$ para $76,7 \%)$. A digestibilidade da semente de maracujá fol afetada por seus níveis crescentes na dieta, havendo decréscimo de digestibilidade da matéria seca $(56,0$ para $36,0 \%)$, extrativo não nitrogenado $(74,5$ para $36,2 \%)$ e extrato etéreo $(94,0$ para $81,1 \%)$. A digestibilidade da proteina (média de $89,1 \%$ ) e fibra bruta (média de $10,5 \%$ ) não foi afetada. o valor médio de NDT da semente de maracujá, considerados os três níveis, foi $64,88 \%$. 


\section{INTRODUÇÃO}

Rações comerciais para bovinos alcançam altos preços no Nordeste brasileiro. Na mesma região, embora o rebanho bovino, especialmen te o leiteiro, possua baixo potencial de produção, há alguns produtores que contam com planteis capazes de responder economicamente ao uso de alimentos concentrados. Assim, dado o fator preço das rações comerciais para aqueles rebanhos, normalmente são utilizados subprodutos industriais como - farelo de côco, a torta de algodão, a torta de mamona atoxicada, o farelo de milho, a semente de maracujá e outros. No que se refere à semente de maracujá, pouco se conhece sobre seu valor nutritivo.

Em função de características sazonais dos subprodutos já referidos, suas disponibilidades e seus preços oscilam no transcorrer do ano, tornando-se da maior conveniência contar-se com dados sobre o valor nutritivo de todos eles.

$\mathrm{Na}$ ausência de dados estatísticos sobre a produção de mara cujá no País procedeu-se um levantamento em algumas das indústrias de bene ficiamento, sendo que três das mesmas, uma do Estado de São Paulo, uma do 
Estado da Bahia e a terceira do Estado de Alagoas, informaram um montante de 12.300t de frutos beneficiados em 1977. Considerando-se os dados de SJOSTROM e ROSA (1978) segundo os quais as sementes perfazem, em média, $11,8 \%$ do fruto, estimou-se una disponibilidade entre 1.400 a $1.500 t$ de sementes para as três indústrias pesquisadas. Por outro lado sabe-se que estas inđústrias não são as ünicas nem, provavelmente, as maiores no País, havendo assim a certeza de uma disponibilidade mais elevada que a constata da, de sementes, para eventual utilização na alimentação animal.

Os objetivos deste trabalho foram: (a) avaliar a digestibi lidade aparente da semente de maracujá e (b) avaliar o efeito de três níveis de semente de maracujá sobre a digestibilidade da ração total em carneiros adultos. 


\section{REVISTOO DE ITTERATURA}

\subsection{Semente de maracujá}

A semente de maracujá (Passiflora edulis sims. forma flav 1 carpa, Deuger) utilizada no presente trabalho é um subproduto da industria lização daquela fruta para a produção de suco.

As publicações sobre composição de alimentos consultados não se referem à semente de maracujá. SNEDDEN (1937) cita o valor de 56,0\% para a fibra da torta de semente de maracujá e ARIKI et alii (1977) encontraram a seguinte composição proximal para a semente integral: matéria seca $88,39 \%$, proteina bruta $9,56 \%$, extrato etéreo $4,62 \%$ e matéria mineral 1,28\%. IANDGRAF (1978), comentando as possibilidades industriais do maracu já, cita teores de óleo entre 22 e $28 \%$ para as sementes daquele fruto, o que contrasta de forma acentuada com os dados de ARIKI et alii (1977).

Nenhum trabalho de pesquisa foi encontrado sobre o uso da semente de maracujá em alimentação de ruminantes. Uma única recomendação de base empírica foi localizada, feita por LANDGRAF (1978). Segundo este 
autor $1 \mathrm{~kg} /$ dia de semente deve ser a quantidade máxima fornecida a bovinos, ressaltando que consumos mais elevados levam a "problemas digestivos".

Para a alimentação de monogástricos, IANDGRAF (1978) indica que suinos podem consumir até $3 \mathrm{~kg}$ dtários de semente. ARIKI et ali1 (1977) usaram, em rações para frangos, até $8 \%$ das sementes moidas na ração total, com resultados semelhantes em termos de ganho de peso, consumo de ração e conversão alimentar, quando comparado aos obtidos com rações convencionais para frangos.

\subsection{Consumo voluntário de alimentos}

Muitos são os fatores que afetam o consumo voluntário de alimentos pelos ruminantes. Características individuais dos animais podem determinar a aceitação ou rejeição do material que Thes está sendo oferecí do como alimento. Variações anatômicas e/ou físiológicas relacionadas com maior ou menor capacidade de volume do trato digestivo, eficiência do sistema de neutralização e excreção de eventuais princlpios tóxicos ingeridos e integridade dos sentidos relacionados com a palatabilidade do material que está sendo oferecldo, são alguns exemplos de fatores que podem de terminar variação no consumo. ARNOLD (1966) usou processos cirúrgicos para eliminar os sentidos do paladar, olfato e tato em carneiros, submetendo-os posteriormente a pastejo, en variadas circunstâncias, juntamente com animais integros. 0 trabalho mostrou que a seletividade de alimentos continuou ocorrendo entre os animais lesados. Todavia, em muitos casos, no sentido inverso da seleção feita pelos animais íntegros. 
Se a capacidade de perceber a palatibilidade de um determi nado alimento pode ser modificada influenciando seu consumo, conforme ficou evidenciado no estudo anterior, variações nas características que determinam a palatibilidade, como odor, sabor, textura, etc., e que são inerentes a cada alimento, certamente também afetarão o consumo voluntário de cada alimento.

Embora o consumo esteja comelacionado com a palatibilidade, para que o animal possa continuar ingerindo alimento é excencial a dis ponibilidade de espaço físico no trato digestivo, conforme ficou evidencia do por WESTON (1966). Este autor alimentou carneiros com diferentes dietas durante uma fase preliminar de 7 a 16 dias e mediu o consumo de cada dieta neste período; em seguida introduziu no rumen dos animais, através de fístula um percentual do mesmo alimento, calculado sotre a quantidade ingerida na fase preliminar. Deixou também o mesmo alimento a dos animais para consumo voluntário e à vontade. A ingestão total de alimento, via fístula e via consumo voluntário, neste perĺodo, foi semelhante aos totais ingeridos no período preliminar, para cada dieta. Concluiu-se que neste caso 0 fator limitante do consumo foi a capacidade do trato digestivo e não a palatibilidade do alimento.

Nas dietas com baixo teor de proteina o nível deste nutriente também tem sido relacionado positivamente com o consumo de alimento. WESTON (1967) fez infusão de uréia e caseina no abomaso de carnejros que recebiam uma dieta com $4,4 \%$ de proteina. Em dois experimentos, a uréia pro vocou pequena depressão em um caso e no outro aumentou o consumo em aproxí madamente 10\%. Quando a caseina foi utilizada, houve aumento de consumo de 
14 e 13\% em relação a um período básico, nos dois experimentos, respectiva mente. Tanto a uréia quanto a caseina suplementaram $0,4 \mathrm{~g}$ de nitrogênio por $100 \mathrm{~g}$ de alimento ingerido voluntariamente. Em um outro experimento relatado também por WESTON (1967), 4\% de gluten fol adicionado a uma dieta com nível proteico de $4,4 \%$, aumentando de forma significativa o consumo de for ragem pelos carneiros, em $8 \%$.

Também visando estudar o efeito do nível proteico da dieta somre o consumo, ELLIOTT e TOPPS (1963) mediram, em quatro experimentos, o consumo voluntário de alimento por carneiros que dispunhan de quatro dietas com níveis de proteina crescentes de 4 até $10 \%$, Os resultados mostraram aumento de consumo em todos os experimentos quando o nível proteico fol elevado de 4 para $6 \%$, e em alguns casos houve aumento do consumo quando a proteina passou a $8 \%$ da ração.

Os trabalhos de WESTON (1967) e de ELLIOTT e TOPPS (1963) indicam sempre uma associação positiva entre elevação do teor proteico e aumento de digestibilidade nas dietas baixas em proteina. A maioria dos autores atribuem 0 incremento na digestibilidade a um estínulo sobre a atividade microbiológica no rumen, conforme se discute, neste trabalho, no ítem que trata do efeito do nível proteico da dieta sobre sua digestibilidade. Entretanto, o aumento no consumo é sempre mais que proporcional ao aumento na digestibilidade, Indicando haver outros fatores envolvidos no processo.

A gordura é outro componente da dieta que pode afetar o consumo por ruminantes. KOWAICZYK et alii (1977) observaram, usando cordei ros de $16 \mathrm{~kg}$, uma relação inversa entre o nível de consumo de uma gramínea 
desidratada oferecida à vontade e a quantidade ingerida de um suplemento energético.

Embora predominam na Iiteratura resultados que demonstram uma ação negativa da gordura sobre a digestibilidade da fração fibrosa do alimento quando a graxa se eleva acima de aproximadamente $6 \%$ na ração total, tal fato parece não ocorrer em todas as circunstâncias. Em um trabaTho com vacas em lactação PAIMQUIST e CONRAD (1978) estudaram o efeito de dois nf́veis de um suplemento energético a base de gordura hidrolisada sobre a ingestão e digestibilidade da ração. Os autores forneceran aos animais um concentrado com zero e $10 \%$ do referido suplemento, além de um volu u moso, em proporções tais entre concentrado e volumoso que a dieta com teor mais elevado de extrato etéreo o fosse também em fikra. As dietas eram iso energéticas e apresentavam os seguintes níveis de extrato etéreo: 3,30 , 2,88, 5,90 e 6,80. Em um segundo experimento executado pelos mesmos autores, estudando o mesmo suplemento energético, o extrato etéreo foi elevado na dieta total até 10,8\%. Em nenhum dos casos foi observada diminuição da ingestão de alimento, nem tão pouco foi deprimida a digestibilidade da fibra. Os autores atribuem estes resultados, discrepantes em relação à maior parte da Iiteratura quanto à digestibilidade de fibra, aos efeitos da maior ingestão de alimentos por vacas en lactação, o que por si só já dimí nue a digestibilidade daquele componente, e ainda $\dot{a}$ uma ingestão mais lenta do alimento que seria determinada pela gordura adicionada.

De uma forma geral, a correlação inversa entre níveis elevados de gordura na dieta e ingestão de alimentos por ruminantes pode ser atribuida a uma diminuição na digestibilidade da fibra bruta, conforme é 
discutido no item sobre fatores que afetam a digestibilidade dos alimentos, nesta revisão. Um segundo ponto importante da mesma. questão è a relação entre densidade calórica e seu nível de ingestão. BAUMGARDr (1970) cita um trabalho próprio, com carneiros castrados, tendo fornecido aos animais uma dieta básica constituida por um concentrado, diluido de 5 a $50 \%$, a interva los de cinco unidades percentuais, respectivamente com pó de serra, pó de serra mais argila e pó de serra mais farinha de soja, de modo a se obter dietas isonitrogenadas em todos os níveis de diluição. As conclusões mostram que a ingestão de alimento crescem à medida que crescem o nível de energia digestivel da ração, até o valor de $2,5 \mathrm{kgcal} / \mathrm{g}$ de alimento. A par tir deste ponto, a ingestão de alimento diminuiu, mantendo-se estável a in gestão de energia digestivel.

A análise da vasta literatura existente sobre consumo voluntário de alimentos por ruminantes indica que a decisão de aceitar ou re jeitar, consumir mais ou consumir menos um determinado alimento é sempre muito mais função de interação entre muitas variaveis do que efeito de uma delas isoladamente.

\subsection{Alguns fatores relacionados com a digestibilidade}

A digestibilidade dos alimentos é afetada por um número elevado de fatores. O sentido e a intensidade com que cada um desses fatores atua nem sempre está claramente definido, conforme se pode perceber consultando revisões existentes sobre o assunto.

Nesta revisão serão abordados apenas os fatores relaciona- 
dos com a discussão dos resultados do presente trabalho.

\subsubsection{Nível de ingestão}

A quantidade de alimento ingerido interfere com o tempo de permanencia do ingesta no trato digestivo do animal. Quanto mais rápida a velocidade de passagem, tanto menor o tempo de ação dos processos digestivos e de absorção de nutrientes, o que resulta em maiores perdas destes $\dot{u}_{\underline{I}}$ timos através das fezes. De fato, segundo a maioria dos trabalhos da ampla revisão feita por SCHNEIDER e FLATT (1975), maiores nf́veis de ingestão levam a uma diminuição de digestibilidade. Entretanto, conforme a natureza do alimento, menor digestibilidade não significa necessariamente menor vaIor Ifquido no suprimento de energia para o animal. BAUMGARDT (1970) cita dados de FIATT et alii (1966) que observaram ingestões diárias de 45,0, 43,6 e 41,9 Mcal de energia digestivel, $38,7,38,7$ e 37,7 de energia meta bolizavel e $19,3,19,4$ e 19,5 de energia líquida, com rações de valor ener gético crescente.

A partir da revisão de SCHNEIDER e FLATT (1975) e do traba Tho de WAGNER (1965), citado por TYRREIL e MOE (1975), infere-se que se dispondo de um bom volumoso, com teor proteico acima de $15 \%$ como dieta básica, e acrescentando-se a esta niveis crescentes de concentrado de modo a aumentar o volume de alimento consumido, deve-se esperar uma diminuição na digestibilidade da ração à medida em que a participação do concentrado na dieta, aumenta. Tal fenômeno provavelmente está associado ao aumento na ve locidade de passagem do ingesta pelo trato digestivo, aumento este que é determinado não só pelos níveis crescentes de ingestão, como também pela 
maior presença de concentrado na dieta.

A relação entre nívei de ingestão e digestibilidade do ali mento nem sempre é de ordem inversa. A análise de alguns trabalhos serve para ilustrar a variabilidade dos resultados encontrados pelos diversos au tores que estudaram a forma de associação entre os parâmetros em discussão. GRAHAM et alii (1959), estudando, através de carneiros, o nível de ingestão sobre a digestibilidade do alimento constituido por cubos de gramínea desidratada, com teor proteico de $12,9 \%$, fornecidos nas quantidades de 600 , 1200 e $1800 \mathrm{~g} / \mathrm{dia}$, observaram apenas um decréscimo de 59,3\% para 54,7\% na digestibilidade da energia, entre o nível mais baixo e o mais alto de alimentação, não sendo constatadas diferenças entre os demais níveis. TAGARI et alii (1977) a valiaram o efeito da desidratação e do congelamento sobre a digestibilidade do capim Rhodes (Chloris gayana), com média de 14,9\% de proteina bruta, quando aquele constituia $30 \%$ de uma dieta que foi forneci da a carneiros, em dois níveis 579 e $1113 \mathrm{~g} / \mathrm{dia}$, de matéria seca, para a dieta que continha a gramínea congelada e 572 e $1145 \mathrm{~g} / \mathrm{dia}$, de matéria seca, para a gramínea desidratada. Em nenhum dos dois tipos de dieta foi constatada diminuição de digestibilidade com o aumento no nível de ingestão; pelo contrário, houve tendência a aumento da digestibilidade dos nutrientes ao nível de ingestão mais alto.

Mesmo para alimentos ricos em fibra, como a palha de soja, nem sempre a variação no nível de ingestão determina modificações na diges tibilidade. GUPTA et alii (1978) forneceram palha de soja contendo $67,4 \%$ de parede celular a carneiros, em dois níveis, de modo que fossem ingeridas 30,6 e $21,4 \mathrm{~g}$ de matéria seca por quilo de peso vivo, por dia. Não fọ 
ram constatadas diferenças significativas para a digestibilidade dos nutri entes, entre nf́veis.

Tendo em vista a possibilidade de alterações na digestibilidade dos alimentos quando diferentes quantidades dos mesmos são ingeridas em um determinado intervalo de tempo, conclue-se ser desejável, do pon to de vista da segurança dos dados obtidos, que seja mantida ao máximo a constância na ingestão diária de alimento, em experimentos de digestibilidade.

\subsubsection{Composição do alimento}

\subsubsection{Fibra}

Em condições naturais, a dieta dos ruminantes é constituida de forragens com elevados teores de fibra, sem que haja maiores problemas para a sobrevivência dos animais. Em exploração intensiva, contudo, a exigência de grandes produções presupõe elevada eficiência digestiva e neș ta circunstância tanto o teor quanto a qualidade da fibra passam a ser fatores Iimitantes.

A fração do alimento denominada "fibra bruta" varia em sua composição e nas proporções dos seus componentes, de acordo com o alimento. A utilização de volumosos à base de gramíneas, introduz na dieta fibra com teor de celulose variando entre 39 e $47 \%$, hemicelulose entre 37 e $49 \%$ e lignina entre 6 e 13\%; o uso de leguminosas como forragens implicará em níveis diferentes de componentes da fibra: celulose entre 42 e 58\%, hemice 
lulose entre 22 e $31 \%$ e lignina entre 18 e $24 \%$ (SHINGH et al1i, 1976). Estes dados foram obtidos de amostras coletadas quando cerca de $50 \%$ das plan tas já havia florecido, com várias espécies em cada famflia, e servem apenas para ilustrar a variabilidade de composição da fibra entre espécies dí ferentes dentro da mesma família e entre diferentes famílias, desde que o estado de desenvolvimento da planta é também determinante da composição de sua fibra (JOHNSTON e WAITE, 1965).

Isoladamente, o componente da fração fibrosa ao qual se atribue maior interferência na digestibilidade da fibra é a lignina. NORTHCOT (1972), em revisão sobre a formação da parede celular vegetal, relata que na última etapa daquele processo a lignina é depositada formando uma cobertura sobre as microfibrilas celulolíticas e provavelmente associando-se às mesmas através de ligações químicas do tipo covalente.

Muitos trabalhos têm sido desenvolvidos procurando estudar a interferência da Iignina na digestibilidade do alimento. AKIN et alii (1977) utilizaram três técnicas intercomplementares para avaliar o efeito do amadurecimento sobre a composição e digestibilidade "in vitro" do capim de burro (Cynodon dactylon (I) Pers). Inicialmente foram analisadas, quimi camente, pontas, meios e bases de lâminas de folhas, bainhas e colmos. Em seguida, amostras das mesmas porções foram submetidas a digestibilidade "in vitro". Por último o resíduo indigerido proveniente da fase anterior foi submetido a observação em microscópio eletrônico para constatação da ação digestiva sobre os diversos tipos de tecido. Os resultados, com exces são dos observados para as lâminas de folnas, mostrarm um aumento no teor de Iignina da ponta para a base de cada porção, uma diminuição na digesti- 
bilidade "in vitro" no mesmo sentido, e uma abrangência maior de lignifica ção nas partes mais velhas (meios e bases de cada porção). Os autores não conseguiram, por outro lado, associar mudanças devidas à maturidade, nos padrões de fibra neutro-detergente, celulose e hemicelulose, com a mudança na digestibilidade das diversas partes da planta. HAN et al11 (1975), contudo, estudaram o efeito digestivo de enzimas ligninolíticas e celulolíticas sobre diversos vegetais contendo valores elevados de fibra bruta. Os resultados mostraram alta correlação negativa $(r=-0,93)$ entre teor de lignina na forragem e sua digestibilidade "In vitro". Também o teor de celulose foi correlacionado negativamente $(r=-0,90)$ com a digestibilidade "In vitro", mais uma análise de correlação múltipla mostrou que no complexo celulose-lignina, esta última, principalmente foi a que mais afetou negativamente a digestibilidade. Os níveis de hemicelulose, por sua vez, foram correlacionados positivamente com a digestibilidade "in vitro".

Apesar das evidências demonstrando os efeitos negativos da lignina sobre a digestibilidade da fibra, parece que para exercer seu efe 1 to aquela substância precisa estar incorporada de forma natural, pela própria planta. HAN et alii (1975) testaram a digestibilidade "in vitro" de palhas, incorporando previamente de $I$ a $20 \%$ de lignina à palha. Não houve diferenças significativas entre tratamentos.

Outro importante componente da fração fibrosa nos vegetais é a cutina, principalmente na estrutura protetora dos cotilédones das sementes. VAN SOEST e ROBERTSON (1976) afirmam que "a membrana que cobre as sementes da maioria das angiospermas é uma capa protetora e é, portanto, mais fibrosa e as vezes fortemente lignificada. A cobertura das sementes 
frequentemente contem muita cutina associada com a fração lignina bruta, a qual tem igual efeito sobre a redução da digestibilidade" .

0 estudo sobre a digestibilidade de "in vivo" de rações completas mostra o mesmo tipo de associação entre teor de fibra e digestibilidade, já ressaltado pelo processo "in vitro". WHITE et alii (1974) ava liaram o efeito de níveis crescentes (zero, 20, 40,60,80 e 100\%) de paTha de arroz e de feno de capim de burro, na dieta de novilhos, sobre a digestibilidade da palha. Os autores observaram, em ambos os volumosos, aumentos lineares e quadráticos significativos quanto a digestibilidade da fibra bruta da dieta; diminuição na digestibilidade da energia, matéria sẹ ca, matéria orgânica, extrativo-não-nitrogenado e extrato-etéreo, foi observada com o aumento dos níveis do feno de capim de burro ou da palha de arroz, exceto para o extrato-etéreo, cuja digestibilidade não foi alterada, neste último caso. Os efeitos em todos os parâmetros, para os tratamentos contendo palha de arroz foram lineares e quadráticos. Os resultados indicam uma variação diferenciada na capacidade fermentativa do rumen de acordo com os componentes da dieta; indicam também diferenças de intensida de sobre o efeito da variação da fibra bruta e extrativo-não-nitrogenado da ração. A análise dos dados numéricos mostra também um comportamento diferente entre as fibras dos dois volumosos: o incremento na digestibilidade da fibra do feno de capim de burro, com as elevações do mesmo na dieta, é maior que o constatado para a palha de arroz em condições idênticas, mas o efeito depressivo desta última sobre a digestibilidade da energia bruta, da matéria seca e da matéria orgânica da ração total, é acentuadamente mais intensa. Esta últimas observações provavelmente poderiam ser explicadas a partir dos componentes da fração fibrosa das duas forragens e de 
substâncias associadas àquelas frações (sílica, por exemplo).

Os efeitos depressivos de fibra sobre a digestibilidade da matéria seca da ração, assim como sua ação estimuladora sobre a própria di gestibilidade, podem ser constatados também através de trabalhos como o de SUDWEEKS (1976) que usou, em um ensaio de digestibilidade com carneiros, quatro diferentes tipos de grãos (cevada, milho, farinha de soja e trigo), em três níveis $(20,40$ e 60\%) na ração, juntamente com a casca de semente de algodão, como volumoso. A análise dos efeitos dos tratamentos, quanto à digestibilidade, da fibra bruta e celulose, mostram uma tendência descendente quando os teores de grãos das diețas aumentam. Outro aspecto a ser observado é que a digestibilidade da fibra bruta foi sempre menor e mais susceptível às variações dos níveis de gxãos que a observada para a celulo se, com quaisquer dos tipos de grãos utilizados. Tal fato, mais uma vez, indica que a digestibilidade da fibra bruta sofre influência não só de sua quantidade na dieta como também das proporções dos seus próprios elementos componentes, ou seja, de sua qualidade.

\subsubsection{Extrativo-não-nitrogenado}

O extrativo-não-nitrogenado (ENN) é composto basicamente de carboidratos soluveis em ácido sulfúrico e hidróxido de sódio, ambos em solução $0,25 \mathrm{~N}$. Sua fermentação no rumen é elevada e rápida sob a ação dos microorganismos. Deste processo resulta parte da energia utilizada para a manutenção da flora e da fauna ruminal, assegurando seu equilíbrio, e de substâncias úteis ao hospedeiro. Contudo, disponibilidade excessiva de cax boidratos solúveis leva a acúmulo de substâncias intermediárias durante o 
processo fermentativo, as quais trão modificar as condições no rumen, selecionando determinados tipos de microorganismos e consequente, afetando a digestibilidade do alimento como um todo.

SUDWEEKS (1976) refere-se, em uma revisão sotre efeitos dos níveis de ENN sobre a digestibilidade, aos dados de OLTJEN (1970) que relata três trabalhos nos quais foram isoladas bactérias do ingesta de novilhos alimentados exclusivamente com concentrado, contendo $90 \%$ de quirera de milho, ou 90\% de quirera de trigo, ou uma combinação de 60:30 dos dois grãos. Havia bactérias celulolíticas em todos os novilhos, mas não em núme ro suficiente para serem detectadas em um meio não seletivo. Os novilhos sob dieta de trigo apresentaram o mais baixo pH, a menor concentração de protozoários e a maior concentração de Lactobacillus spp. e outras bactérias acidófilas, no rumen.

Trabalhando com casca de semente de algodão e quatro tipos de grãos (cevada, milho, farinha de soja e trigo), em três níveis na ração (20, 40 e 60\%) SUDWEEKS (1976) encontrou resultados de digestibilidade por carneiros, mostrando um aumento sobre a digestibilidade do ENN de 68,1 para 76,5\% com a elevação do teor de grãos na dieta, ocorrendo o oposto com a digestibilidade da fibra, de 51,7 para 41,3\%. Também a digestibilidade da matéria seca, aumentou com o crescimento do teor de grãos na dieta, de 58,9 para $64,8 \%$. A proteina teve sua digestibilidade elevada apenas quando os grãos foram aumentados de 20 para $40 \%$ da ração, de 41,3 para $51,7 \%$. Mais recentemente SUDWEEKS (1977) trabalhou com carneiros e avaliou a digestibilidade da polpa cítrica, resíduo de farinha de soja e torta de soja, como concentrados, adicionados aos niveis de 10,40 e $70 \%$ à silagem de mi- 
Iho, silagem de sorgo e feno de capim de burro. A quantidade de ENN ingeri da não foi constante nem dentro de, tão pouco concentrados. Todavia, na mé dia houve um aumento significativo da digestibilidade do ENN, passando de $69 \%$ ao nível de $10 \%$ de concentrado, para $81 \%$ quando aquele componente da dieta subiu a 70\%. A digestibilidade da matéria seca tarbém aumentou com os níveis mais altos de ENN. A digestibilidade da proteina aumentou de 64 para $71 \%$ com o primeiro aumento no teor de grãos, permanecendo, em seguida, estável.

STONE e FONTENOT (1965) forneceram a novilhos rações contendo três níveis de energia, 62,67 e $72 \%$ de NDT, e fibra bruta em níveis de $23,0,17,9$ e $12,0 \%$. Os resultados obtidos mostraram úm incremento na di gestibilidade do ENN, de 67,4 para 77,0\%, na matéria seca de 63,6 para 69.5\% e uma diminuição na digestibilidade da fibra bruta, com a elevação do nível de energia na ração. Não foram encontradas diferenças para a digestibilidade da proteina bruta quando os níveis de energia foram alterados.

Os dados obtidos por todos os autores citados mostram: (a) tendência de decréscimo da digestibilidade da fibra com o aumento do nível de ENN na dieta, (b) tendência para aumentar a digestibilidade do próprio ENN, da proteina bruta e da matéria seca, com a elevação do primei ro na dieta.

EL-SHAZLY et alii (196I) estudaram, "in vitro" e "in vivo", o efeito do amido sobre a digestibilidade da celulose. Quando usaram apenas o líquor ruminal, $2 \mathrm{~g}$ de celulose e $I$ ou $2 \mathrm{~g}$ de amido, observaram uma inibição crescente da digestibilidade da celulose pela presença do amido, 
mesmo quando os produtos da fermentação, na forma de $\mathrm{H}^{+}$do meio, foram dia Iizados. A adição de nitrogênio ao processo provocou uma resposta favorável à digestibilidade, sendo a uréia a fonte, ao nível de 177mg/dl. Os estudos "in vivo" também mostrarm efeitos benéficos da adição de uréia $(69 \mathrm{~g} / \mathrm{dia})$ enquanto a relação feno:milho na dieta fornecida aos carneiros foi de $1: 1$. Quando a relação passou a ser $1: 2$, mesmo aumentando o fornecimento de uréia para $48 \mathrm{~g} / \mathrm{dia}$, a digestibilidade da celulose permaneceu inal teradamente baixa. Não são apresentadas informações sobre o pH e teor de ácido lactico no rumen, os quais principalmente neste último caso, poderiam auxiliar na interpretação dos resultados. Mesmo assim, as observações sugerem a existência de dois fatores básicos contribuindo para a diminuição da digestibilidade da fibra em presença de níveis crescentes de ENN: a competição por nutrientes escassos, entre os microorganismos que atuam na digestão de ENN e os que hidrolisam celulose, e um segundo fator que prova velemnte estaria relacionado com os subprodutos da fermentação.

A relação positiva encontrada, de um modo geral, entre o nível de ENN e sua digestibilidade é atribuida por ANNISON e IENIS (1959) citados por STONE e FONTENOT (1965), a um rápido crescimento no número de microorganismos capazes de fermentar aqueles carboidratos solúveis, à medi da que a referida fração aumenta. De fato, EL-SHAZLY et alii (1960) citados por EL-SHAZIY et alii (1961), observaram microscopicamente que microco cus Gram-negativos e pequenos bastonetes proliferaram "in vitro" e "in ví vo" quando a celulose serviu como único ou principal carboidrato do substrato. Quando o amido foi adicionado aos frascos os tipos celulolíticos fo ram substituídos amplamente por bastonetes maiores Gram-negativos e ovalados, cocoides, e diplococus Gram-positivos. 
Quanto ao efeito dos níveis de ENN sobre a digestibilidade da proteina, observa-se que o mesmo se faz notar somente nos nfveis mais baixos de energia. Tal constatação sugere que a indisponibilidade de energia em níveis suficientes, leva a perdas de proteina bruta fermentada em amonia no rumen, provavelmente por insuficiência de microorganismos para aproveita-la em tempo habil, e por deficiência no suprimento da energia de mandada pelo processo.

O aumento da digestibilidade da matéria seca com os níveis mais altos de ENN reflete o efeito do preponderante aumento na digestibili dade do próprio ENN e da proteina, em relação à diminuição da digestibilidade da fibra bruta.

3.3.2.3. Proteina bruta

Como os demais fatores que interferem na população microbiana do rumen, a proteina bruta da ração também interfere sobre a digesti bilidade dos alimentos (SCHNEIDER e FIATT, 1975).

Constam da literatura resultados aparentemente controverti dos, principalmente sobre a associação entre nível de proteina da dieta e digestibilidade da fração flbrosa. Tais controversias provavelmente podem ser explicadas pela complexidade dos fatores e das interações envolvidos na digestão dos alimentos pelos ruminantes. lestas circunstâncias, dificil mente caia trabalho é executado em condições idênticas aos demais, sendo obtidos, assim, resultados às vezes diversos. 
Para avaliar o efeito do decréscimo no teor de proteina da dieta de novilhos, RAVEN et ali1 (1969) usaram um concentrado com $15 \%$ de proteina bruta como testemunha, e adicionaram 10,20 e $30 \%$ de palha de cevada ao concentrado básico, obtendo rações com $14,4,13,2$ e 12,0\% de proteina bruta. Em um outro experimento concomitante, os três niveis de palha foram adicionados a outros três concentrados, formulados de forma a manter - nível final da proteina, após adição da palha, por volta de 15,5\%. os re sultados mostrarm um incremento na digestibilidade da fibra bruta, com ou sem manutenção do nível básico de proteina, quando os níveis de palha na dieta aumentaram. A digestibilidade da matéria orgânica, do ENN e da proteina diminuiram com a adição de palha, nos dois experimentos. Todavia, a adição de palha aos concentrados aiminuiu o nível de ENN na dieta, e assin - efeito negativo sobre a digestibilidade das frações e da matéria seca fi cou confundido pela variação simultânea dos dois fatores.

ABOU AKKADA e EI-SHAZLY (1958) estudaram o efeito de várias fontes de proteina, provenientes de diferentes concentrados, e ainda diferentes niveis de proteina da mesma origem, sobre a digestibilidade da celulose da ração, basicamente constituida de palha de trigo.

Os resultados não mostraram diferenças significativas entre tratamentos, nem para fontes, nem sempre para niveis de proteina. 0 n vel de consumo de palha foi de aproximadamente $1.000 \mathrm{~g} / \mathrm{dia}$, e seu teor de proteina bruta era de 1,73\% na matéria seca. A quantidade de concentrado consumido diariamente, porém, não é fornecida pelos autores, o que impede a interpretação dos resultados, por näo ser possivel estabelecer-se o nível de proteina na dieta total. 
Os resultados encontrados por EL-SHAZLY et alii (1961), trabalhando com carneiros aos quais fornecem uma ração constituida de feno maiss milho triturado na proporção de 1:1, suplementada com 16, 26, 32 e $52 \mathrm{~g}$ de uréia, indicam claramente o efeito benéfico do nitrogénio sobre a digestibilidade da fibra, dentro dos limites estabelecidos naquele trabaIho. Outros autores tem encontrado resultados semelhantes. ELIIOT e TOPPS (1963) avaliaram a digestibilidade, por carneiros, de três rações com composições diferentes e com quatro níveis proteicos (4,6, 8 e 10\%) para cada ração. Embora o objetivo principal do trabalho fosse associar digestibi lidade da ração com ingestão voluntária, a análise dos dados mostrou uma associação positiva entre digestibilidade e nível de nitrogênio da dieta, com efeitos mais evidentes para os niveis mais baixos. Também WESTON (1967), trabalhando com carneiros, forneceu aos animais uma dieta básica de feno de trigo com 4,3\% de proteina (100, 96 e 85\% da dieta total) mais gluten com $11,5 \%$ de proteina, nos dois últimos tratamentos ( 4 e $15 \%$ da dieta total). Os resultados mostraram um aumento significativo na digestibilidade dos constituintes da parede celular proveniente exclusivamente do feno de trigo, 52,6\%, quando foi adicionado $4 \%$ de gluten à dieta, e nenhum outro acréscimo, com a elevação daquele constituinte para $15 \%$ da ração.

Analisando-se o conjunto dos trabalhos revisados, observase que, de fato, o nível de proteina bruta da dieta exerce influencia sobre sua digestibilidade, principalmente quando a taxa daquele componente é baixa. Tal efeito é atribuido por ELIIOTT e TOPPS (1953) a interrelação en tre disponibilidade de proteina/desenvolvimento de microorganismos no ru men e velocidade de fermentação do almento no rumen, possibilitando seu melhor aproveitamento pelo animal. 


\subsection{2... Extrato etéreo}

o extzzto etéreo é constituido por todas as substâncias so lưveis em eter. Sua cenztituição varia, portanto, conforme o alimento. Nos ãos e em seus suzrodutos, a maior parte do extrato etéreo é constituida por gordura vercz=isra, mas nas forrageiras, observa-se naquela fração a presença de piganntos, cêras, etc., o que determina maior variabilidade na sua digestibilìiade. Outras fontes de variação referm-se à gordura saponificada existente aas fezes e a gordura endógena (SCHNEIDER e FIATT, 1975).

As gożzas são compostos ricos em energia, e seu uso para a alimentação de rumirz-tes auxilia para a solução do problema de atender, em termos energéticos, = animais de alta produção, levando-se em conta a limitada capacidade de rolume do rumen. Entretanto as possibilidades de seu uso são limitadas $\cong=i o$ seu efeito depressor sobre a digestibilidade, principalmente da fibrE. KOWALCZYK et alii (1977) trabalharam com cordeiros e com carneiros a $\dot{a}-t o s$, estudando o efeito da graxa sobre a digestibi lidade do alimento. Aos cordeiros foi oferecido capim desidratado $(17,5 \%$ de proteina bruta) a visade, de inicio, e posteriormente se complementou a quantidade ingerida $=2 n 7$ e $14 \%$ de um suplemento rico em gordura (660g de sebo de boi, $320 \mathrm{~g} \dot{c}=$ Ieite desnatado e $20 \mathrm{~g}$ de lecitina/1.000g) na forma de suspensão em água, :-. seca. O suplenento, na forma Iíquida, não interfe riu sobre a digestibil-zae da fibra; contudo, quando oferecido na forma seca, determinou sign:--ativa diminuição na digestibilidade de fibrai contudo, quado ofereciz: na forma seca, determinou significativa diminuição na digestibilidade ¿- fibra, principalmente quando passou do nível ze- 
ro para $7 \%$ da dieta. Tais observações localizaram a ação da gordura sobre a digestibilidade da fibra, a nível de rumen. Aos carneiros adultos, no se gundo experimento, foi oferecido capim desidratado ( $736 \mathrm{~g}$ de matéria seca) dis, com $15,6 \%$ de proteina bruta, $27,7 \%$ de ADF, $20,5 \%$ de celulose e $4,8 \%$ de Iipídios) e foi injetado no rumen, por via fistular zero, 40,80 ou $120 \mathrm{~g} /$ dia de gordura, na forma de sebo. Em cada animal foi avaliada, em sacos de Dracon, a digestão, após 6, 12, 18 e 24 horas de incubação de $5 g$ de gramínea seca e moida, e de cordão de algodão. Os resultados mostraram um decréscimo, em todos os intervalos de tempo estudados, na digestibilidade da matéria seca e da celulose da gramínea e na celulose do cordão, a medida que a quantidade de sebo introduzida no rumen aumentou. Determinações de $\mathrm{pH}$, ácidos graxos livres e amônia no rumen mostraran crescimento significativo dos dois primeiros parâmetros e dininuição do último, com a eleva ção do sebo injetado no rumen. Por último, a determinação de ácidos gráxos voláteis indicou diminuição do ácido acético e aumento do propiônico, o que é compativel com a diminuição na digestão da fibra.

0 mecanismo pelo qual a gordura interfere sobre a digestibilidade da fibra ainda não é bem claro. DEVENDRA e IEWIS (1974), citam di versas hipóteses que tem sido levantadas sobre o fenômeno: uma delas sugere que a gordura envolveria a porção fibrosa, protegendo-a da ação digesti va dos microorganismos; uma segunda hipótese está relacionada com a possível alteração da flora ruminal en presença de altos níveis de eraxa; uma terceira hipótese é que os ácidos graxos teriam una ação inibitória sobre os microorganismos, interferindo na perneabilidade da membrana celular; por Último una quarta admite a possibllidade de uma ação indireta dos ácidos graxos sobre os microorganismos ào runen, através da depleção do cál- 
cio, saponificando-o. O trabalho de KOWALCZYK et alif (1977) acrescenta uma nova hipótese as já existentes, baseada na depressão do nível de amônia no rumen: os autores sugerem que a diminuição da fermentação da fibra estaria associada a indisponibilidade de amonia para o adequado desenvolvimento da flora/fauna ruminal. 


\section{MATERIAIS E MÉTODOS}

o ensaio foi desenvolvido no estábulo experimental do Departamento de Zootecnia da Escola Superior de Agricultura "Luiz de Queiroz", Estado de São Paulo, iniciando-se em novembro de 1978, e sendo concluido em abril de 1979.

\subsection{Tratamentos e delineamento estatístico}

o estudo sobre o valor nutritivo da semente de maracujá foi desenvolvido avaliando-se a sua digestibilidade por diferença (SCHNEIDER e FLATT, 1975), através de carneiros, quando aquele alimento foi adicionado em três niveis a dieta. Determinou-se ainda o efeito desses niveis sobre a digestibilidade da ração total.

Os quatro tratamentos foram estabelecidos a partir de uma dieta básica constituida por $700 \mathrm{~g}$ de fero de capin Phodes e $200 \mathrm{~g}$ de torta de algodão. Substituiu-se zero (tratamento A), 100 (tratanento B), 200 (tratamento C) e $300 \mathrm{~g}$ (tratanento D) do feno, por semente de maracujá, pe- 
so por peso. A torta de algodão serviu como condimento para a semente de maracujá.

A ração foi suplementada com uma mistura mineral comercial que representava aproximadamente $1 \%$ do seu peso, constituida de carbonato de cáicio $(1,30 \%)$, fosfato bicálcico $(4,05 \%)$, óxido de ferro $(0,72 \%)$, sulfato de magnésio $(0,04 \%)$, cloreto de sódio (93.25\%), sulfato de cobre $(0,11 \%)$, sulfato de cobalto $(0,13 \%)$, sulfato de manganes $(0,34 \%)$, sulfato de zinco $(0,04 \%)$ e iodato de potássio $(0,02 \%)$.

0 delineamento experimental adotado foi dois quadrados latinos $4 \times 4$; os periodos experimentais foram de 14 dias sendo 7 dias de adaptação e 7 dias de coleta.

A sequência de aplicação dos tratamentos aos carneiros encontra-se no quadro 1.

Quadro 1. Sequência de aplicação dos tratamentos aos carneiros, por quadrado latino (Q.L.).

\begin{tabular}{|c|c|c|c|c|c|c|c|c|c|}
\hline \multirow[t]{2}{*}{ Períodos } & \multirow{2}{*}{ Carneiros } & \multicolumn{4}{|c|}{ Quadrado Latino I } & \multicolumn{4}{|c|}{ Quadrado Latino 2} \\
\hline & & 8 & 1 & 4 & 6 & 7 & 3 & 2 & 5 \\
\hline I & & A & D & C & B & $A$ & D & C & B \\
\hline II & & $D$ & C & B & A & $D$ & C & B & A \\
\hline III & & $B$ & $A$ & D & C & B & $A$ & D & C \\
\hline IV & & $\mathrm{C}$ & B & $A$ & $D$ & C & B & $A$ & $D$ \\
\hline
\end{tabular}


Os coeficientes de digestibilidade obtidos para cada fração da sementes de maracujá e da dieta total, com valores originais ou transformados em arco seno, foram submetidos à análise da variância. Como não se observam diferenças entre os resultados obtidos a partir dos dados originais ou transformados, optou-se pela apresentação dos primeiros.

Na análise da variância dos coeficientes de digestibilidade das frações da semente de maracujá, a soma de quadrados correspondente a comparação entre níveis de semente foi decomposta em seu componente de regressão linear e quadrática, pelo método dos polinômios ortogonais (PIMENTEI, COMES, 1977).

Na análise de variância dos coeficientes de digestibilidade das frações da dieta total e dos coeficientes relativos as frações da semente de maracujá, os graus de liberdade referentes à interação entre quadrados latinos e tratamentos foram adicionados ao Resíduo já que as referidas interações não'foram estatisticamente significativas (KALIL, 1977).

A comparação entre médias de tratamento foi feita pelo tes te de Tukey, considerando em todos os casos ao nível de $5 \%$ e os coeficientes de regressão foram testados pelo teste $t$, considerando também ao nível de $5 \%$.

\subsection{Obtencão dos componentes de dieta}

As sementes de maracujä utilizadas representan um subprodu to da industria de extração do suco. o processo industrial envolve o corte dos frutos através de facas rotativas, separação de cascas e sementes mais 
arilo sucoso, por meio de escovas apropriadas e, por último, extração do suco, deixando com o resíduo uma massa constituida por sementes e demais componentes do arilo, com a seguinte composição aproximada, quando desidra tada em estufa: matéria seca $38,07 \%$, proteina bruta $10,88 \%$, extrato etéreo $22,57 \%$, fibra bruta $33,55 \%$, matéria mineral $2,47 \%$ e extrativo-não-nitrogenado $30,53 \%$.

Para obtenção da semente utilizada no presente trabalho, dois métodos de secagem foram utilizados: estufa elétrica com ventilação forçada, regulada a $54^{\circ} \mathrm{C}$, por tempo suficiente para que 0 material pudesse ser guardado sem perigo de apodrecimento. O segundo processo de secagem adotado foi o espalhamento do material sobre um peso de cimento, à sombra, até condição idêntica à citada no processo anterior. Este último método foi adotado por não se dispor de estufas com capacidade para desidratar to do o material recebỉdo, tão pouco de área cimentada em local ensolarado.

No experimento foi utilizada a semente seca fora da estufa a qual teve melhor aceitação pelos animais.

O feno utilizado foi proveniente de uma partida preparada no próprio Departamento de Zootecnia da ESALQ, - para uso rotineiro do seu rebanho. Apesar de cuidadosa escolha, verificou-se grande variabilidade en tre os fardos quanto aos percentuais de talos e material estranho, caracte rizando um feno de qualidade de média a baixa, o que determinou uma variação qualitativa entre as rações ao longo do trabalho.

Os pesos, em matéria seca, de cada um dos componentes das rações experimentais encontram-se no quadro 2 . A composição quimicobronato 
lógica aproximada dos três alimentos encontram-se no quadro 3 e as das rações experimentais, no quadro 4.

Quadro 2. Peso (g) da matérła seca dos ingredientes que compuseram as rações em cada tratamento.

\begin{tabular}{lcccc}
\hline \multirow{2}{*}{ Ingredientes } & \multicolumn{4}{c}{ Tratamentos } \\
\cline { 2 - 5 } & $\mathrm{A}$ & $\mathrm{B}$ & $\mathrm{C}$ & $\mathrm{D}$ \\
\hline Feno de Rhodes & 632 & 542 & 451 & 361 \\
Torta de algodão & 90 & 90 & 90 & 90 \\
Semente de maracujá & - & 94 & 189 & 283 \\
Sal mineralizado & 8 & 8 & 8 & 8 \\
\hline Total & 730 & 734 & 738 & 742
\end{tabular}




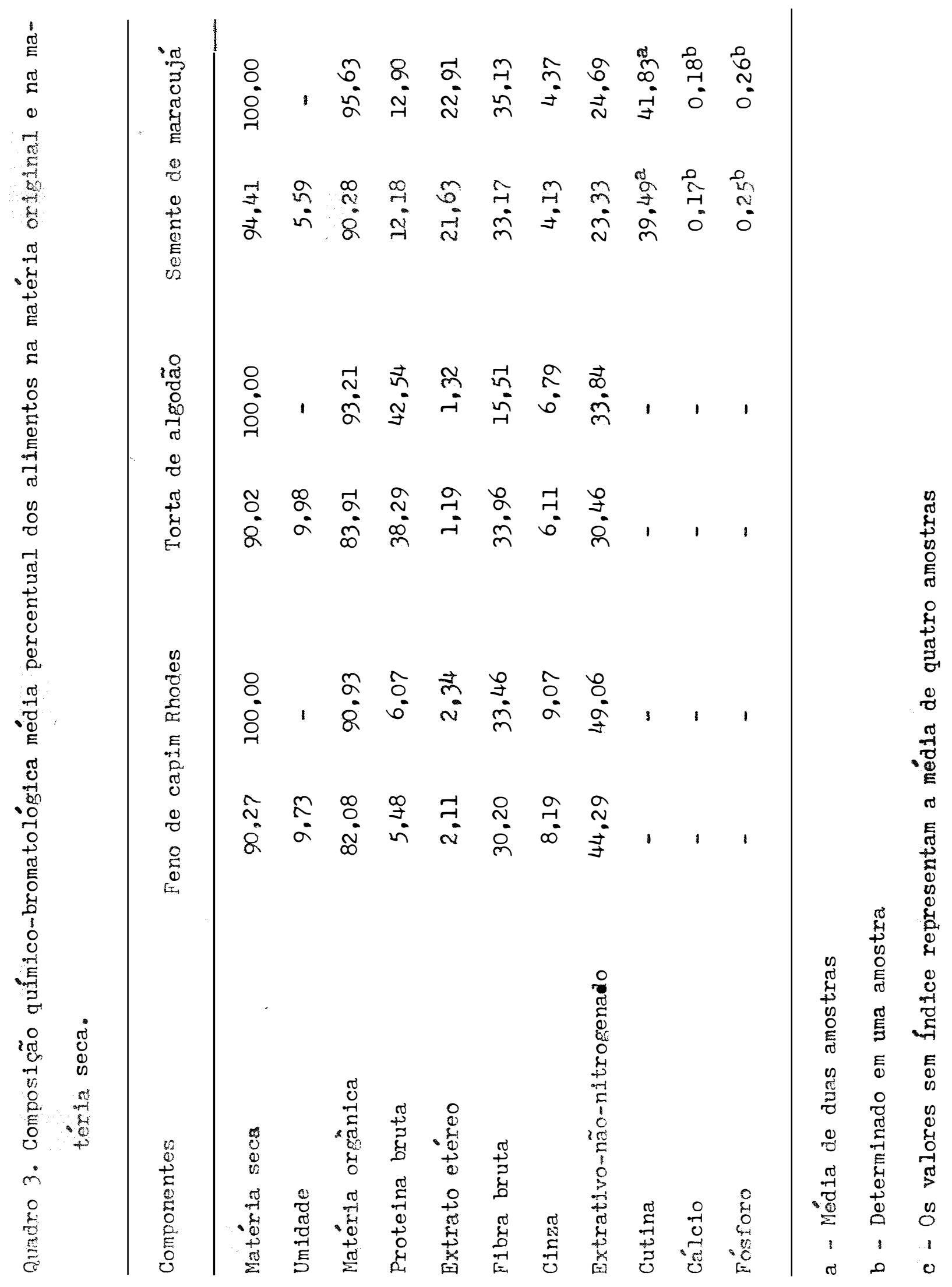


Quadro.4. Composição química média\% na matéria seca da ração em cada um dos tratamentos.

\begin{tabular}{lrrrr}
\hline \multirow{2}{*}{ Constituintes } & \multicolumn{4}{c}{ Tratamentos } \\
\cline { 2 - 5 } & $\mathrm{A}$ & $\mathrm{B}$ & $\mathrm{C}$ & $\mathrm{D}$ \\
\hline Matéria seca & 100 & 100 & 100 & 100 \\
Proteina bruta & 11 & 11 & 12 & 13 \\
Extrato etéreo & 2 & 5 & 8 & 10 \\
Fibra bruta & 31 & 31 & 31 & 32 \\
Extrativo-não nitrogenado & 47 & 44 & 41 & 37 \\
Cinza & 9 & 8 & 8 & 7 \\
Sal mineralizado & 1 & 1 & 1 & 1 \\
& & & & \\
\hline
\end{tabular}

\subsection{Animais experimentais.}

Foram utilizados oito carneiros machos, adultos, castrados, da raça "corridale", com peso médio de $55,3 \mathrm{~kg}$, selecionados dentre quator ze disponíveis, sendo a aceitação da semente de maracujá como alimento, o principal critério de seleção.

Os carnejros foram identificados, tosquiados e vermifugados no início do experimento. Entre o segundo e o terceiro períodos foi feita uma segunda vermifugação no início do período preliminar.

Nos primeiros sessenta dias do trabalino, procurou-se adaptar os animais ao consumo das rações experimentais. Foram realizadas algumas modificações nas características físicas dos ingredientes através de 
moagem e adição de diferentes "condimentos" até se obter um consumo constante.

o feno foi melhor aceito pelos animais na forma inteira, e a semente de maracujá, quando passada por peneira grossa em moinho a marte 10. O "condimento" mais eficiente foi a torta de algodão.

Os animais que consumiram durante três dias consecutivos a ração constituida de $400 \mathrm{~g}$ de feno, $300 \mathrm{~g}$ de semobte de maracujä e $100 \mathrm{~g}$ de torta de algodão, foram considerados adaptados às dietas experimentais.

Cada período experimental foi dividido em uma fase prelimi nar e outra de coleta. Nos quatro primeiros dias da fase preliminar, os animais foram mantidos em baias com extrado de madeira, recebendo a ração que Ihes fora atribuidas de acordo com o sorteio inicial dos quadrados latinos. No quarto dia, cada animal era transferido para uma gaiola de metabolismo onde permanecia até o final da fase de coleta de fezes, voltando então à baia para nova fase preliminar.

No mesmo dia da transferência para as gaiolas, os carneiros eram equipados com sacolas coletoras de fezes, confeccionadas em lona e forradas internamente com saco plástico.

No início do primeiro dia de cada fase de coleta os animais eram pesados, sempre à mesma hora, repetindo-se aquela operação no úl timo dia de coleta.

A ração era divỉida em duas porções iguais, pesadas na véspera e fornecidas diariamente as 8 horas e 17 horas. O fornecimento da 
torta de algodão aos animais que não estavam recebendo semente de maracujá, porém, era feito de uma só vez, pela manhã.

Nos horários de arraçoamento a semente de maracujä mais torta de algodão eram postas à disposição dos animais em primeiro lugar, aguardando-se cerca de 20 minutos para o seu consumo e só então era fornecido. Tal critério estimulava o consumo total da semente de maracujá mais torta de algodão.

Diariamente, na fase de coleta de fezes, uma amostra equivalente a $10 \%$ de cada ingrediente da ração era tomada e guardada em saco plástico. Ao final de cada fase, as amostras eram moidas e acondicionadas em vidros para futuras análises.

A semente de maracujá, após a moagen, era guardada em congelador para evitar possíveis alterações de composição, devido a seu alto teor de öleo.

Água para beber era disponível aos animais durante todo o período e trocada diariamente.

\subsection{Alteracões durante o experimento}

Houve dificuldade para que se conseguisse a ingestão da quantidade mais alta da semente de maracujá utilizada na dieta, 300 g/dia, pelo carneiro no 2 e no 6, e ainda da quantidade intermediária, $200 \mathrm{~g}$, pelo carneiro no 6. o probleme foi contornado através da ingestão forçada daque le alimento nos períodos correspondentes aos niveis citados, através de tu 
bo plástico flexivel.

Os animais no 2,3 e 4 , quando submetidos ao tratamento correspondente à ração constituida por $700 \mathrm{~g}$ de feno e $100 \mathrm{~g}$ de torta de algodão, não conseguiram ingerir todo $\circ$ feno. A solução adotada foi a redução do feno para $500 \mathrm{~g}$ diárias e da torta de algodão para 7lg por dia, de forma a manter a proporção entre os ingredientes, e evitar sobras na fase de coleta de fezes.

0 animal no 2 apresentou um consumo diário de feno bastante irregular no período em que ingeriu de forma forçada, a semente de mara cujá mais torta de algodão.

Entre o segundo e o terceiro períodos, todos os animais fo ram soltos no pasto durante doze dias, na tentativa de se aliviar a tensão causada pelo experimento.

\subsection{Coleta, amostragem e armazenamento de fezes}

As fezes coletadas diariamente durante um periodo de sete dias consecutivos, conforme as recomendações de HALI e WOOLFOLK (1952), STAPLES e DINUSSON (1951), KING et alii (1960) e CLANTON (1961), eram pesa das e amostradas (10\% do peso total) às 8:00 horas de cada dia. Em seguida, as amostras eram acondicionadas em saco plástico e guardadas em congelador para análises posteriores. 


\subsection{Sobras de alimento}

As eventuais sobras de alimento de um determinado dia eram adicionadas à ração do dia subsequente. Ao final de cada fase de coleta, quando as sobras (quadro 5) representavam mais que $10 \%$ do alimento ofereci do, eram guardadas para análise, subtraindo-se seus constituintes do total de nutrientes oferecidos no período, conforme sugeștão de SCHNEIDER e FIATT (1975).

Quadro 5. Sobras, em matéria original (g) das rações, por carneiros e por período

\begin{tabular}{ccccc}
\hline \multirow{2}{*}{ Carneiros } & \multicolumn{4}{c}{ Períodos } \\
\cline { 2 - 5 } & $I$ & $I I$ & $I I I$ & $I V$ \\
\hline 2 & - & $19(\mathrm{C})$ & $47(\mathrm{~A})$ & $I 2(\mathrm{~B})$ \\
3 & $20(\mathrm{C})$ & $44(\mathrm{~B})$ & $57 I(\mathrm{D})$ & $44(\mathrm{~A})$ \\
4 & $2 I(\mathrm{D})$ & $42(\mathrm{C})$ & $80(\mathrm{~A})$ & $107(\mathrm{~B})$ \\
5 & $2 I(\mathrm{C})$ & $39(\mathrm{~B})$ & $32(\mathrm{D})$ & $78(\mathrm{~A})$ \\
6 & $-(\mathrm{B})$ & $42(\mathrm{~A})$ & $15(\mathrm{C})$ & $-(\mathrm{D})$ \\
7 & $-(\mathrm{B})$ & $I 5(\mathrm{~A})$ & $-(\mathrm{C})$ & $-(\mathrm{D})$ \\
8 & $-(\mathrm{A})$ & $-(\mathrm{D})$ & $35(\mathrm{~B})$ & $28(\mathrm{C})$ \\
\hline
\end{tabular}

* As letras entre parênteses representam os tratamentos 


\subsection{Análise de laboratório}

As amostras foram moidas em moinho tipo Willey. Para o fe-i no e a torta de algodão usou-se peneira de 40 mesh, e para a semente de ma racujá, a de 20 mesh, dado a dificuldade de moagem para esta última em fun ção do seu elevado teor de óleo.

As fezes foram desidratadas em estufa elétrica com ventila ção forçada, regulada a $54^{\circ} \mathrm{C}$ de temperatura e moidas em moinho tipo Willey equipado com peneira de 40 mesh. Quando o volume de fezes moidas excedeu àquele considerado suficiente para as análises, além de uma reserva técnica, procedeu-se a uma redução de volume através do redutor de amostra de Jones .

Para cálculo da digestibilidade aparente da semente de maracujá e da dieta total foram feitas nos alimentos e nas fezes, as determi nações do esquema Wendee, conforme as recomendações da AOAC (1975). Na semente de maracujá foi feita a determinação de cálcio e fósforo (AOAC, 1975), cutina (GOERING e VAN SOEST, 1970) e aminoácidos (Analisador Automático de Aminoácidos Bechman 120 c, Secção de Bioquímica de Plantas - CENA, USP). A proteina bruta foi determinada nas fezes antes de submete-las a desidratação em estufa. 


\section{RESULTADOS E DISCUSSÃO}

A semente de maracujá não se enquadra, como alimento, em nenhuma das categorias usualmente adotadas. Seu teor de fibra, por volta de 35\%, caracteriza um volumoso; todavia seu teor de extrato etéreo digestivel médio de $19 \%$ the confere um valor médio de NDT de $65 \%$, aproximadamen te, superior ao do farelo de trigo que é normalmente classificado entre os concentrados.

Com o seu teor de proteina digestivel médio de $10,86 \%$ a semente de maracujá tem um valor, como fonte de proteina, equivalente a 1.8 vezes a do milho amarelo em gxãos, tomando-se para o milho uma proteina digestivel de 5,8\%, conforme ANDRIGUETTO et alii (1978). A composição. de sua proteina, em aminoácidos, encontra-se no quadro 6.

o quadro 3 mostra um teor de fibra bruta $(35,13$, Weende) na matéria seca da semente de maracujá, inferior ao teor de cutina $(39,49 \%$ VAN SOEST) o que indica o valor apenas relativo dos métodos de determinação daquelas frações. De fato, VAN SOEST e WINE (1967) fazem restrições a 
Quadro 6. Composição da proteina bruta da semente de maracujá, em aminoácidos.

\begin{tabular}{|c|c|c|c|}
\hline Componente & $\%$ & & \\
\hline Lisina & 1,74 & & \\
\hline Histidina & 1,64 & & \\
\hline Arginina & 6.57 & & \\
\hline Treonina & 1,43 & & \\
\hline Alamina & 2,19 & & \\
\hline Isolencina & 2,21 & & \\
\hline Leucina & 3,56 & & \\
\hline Fenilalamina & 5,14 & & \\
\hline Metionine & 1,83 & & \\
\hline Valina & 3,35 & & \\
\hline Io sub-total & & 29,66 & \\
\hline Åcido aspártico & 5,74 & & \\
\hline Ácido glutâmico & 14,46 & & \\
\hline Prolina & 2,43 & & \\
\hline GIicina & 1.93 & & \\
\hline Tirostna & 0,88 & & \\
\hline Serina & 1,26 & & \\
\hline Cisteina & 0.87 & & \\
\hline 20 sub-total & & 27,57 & \\
\hline Outros & 42,77 & & \\
\hline Total & & 100,00 & \\
\hline
\end{tabular}


determinação da parede celular em materiais como sementes, dado as dificul dades de filtração que ocorrem em tais casos, elevando o teor para aquele constituinte.

Em virtude da composição químico-bromatológica da semente de maracujá, para determinação de sua digestibilidade foi necessário associa-la à dieta básica de feno majs farelo de algodão, calculando-se a digestibilidade por diferença. Conforme ficou explicitado na revisão de lite ratura, a digestibilidade de cada componente de uma ração, pode variar em função da composição químico-bromatológica final da ração como um todo. Considera-se este fato, o ideal para se conhecer a digestibilidade de um determinado alimento é o seu fornecimento isoladamente aos animais experimentais. Todavia, principalmente no caso de ruminantes, há que se atender a certos pressupostos na prática de sua alimentação; dentre eles, volume mínimo de alimento no rumen e níveis máximos de gordura na dieta não seriam atendidos com o uso exclusivo da semente de maracujá como alimento. Dessa forma recorreu-se à determinação da digestibilidade "por diferença", cujos princípios estão amplamente discutidos em SCHNEIDER e FLATT (1975). Por outro lado, convém lembrar ainda que na prática da alimentação, dificilmente um alimento é utilizado isoladamente, e assim os coeficientes de digestibilidade dos seus componentes estão sempre sujeitos a variações, o que anula em parte as vantagens da determinação da digestibilidade de cada alimento isoladamente. Outra vantagem do processo de determinação da diges tibilidade usado no presente trabalho foi a possibilidade de se contornar a baixa aceitabilidade da semente de maracujá como alimento, pelos carneiros. A torta de algodão usada na dieta básica, em que pese ter adicionado nutrientes à ração, foi utilizada exclusivamente com a intensão de elevar 
o consumo do alimento objeto do interesse, aos niveis desejados, e assim foi classificada como "condimento".

A reação inicial dos carneiros diante do alimento, foi de recusa. Com o passar dos dłas e acompanhando mudanças na forma física, através de moagem grossa, e nas características organolépticas da ração, através da adição da torta de algodão, paulatinamente o consumo aumentou até o nível de $300 \mathrm{~g}$ de semente de maracujá, $100 \mathrm{~g}$ de torta de algodão e $500 \mathrm{~g}$ de feno de capim Rhodes, por dia, para todos os animais. Mantido este consumo por quatro dias consecutivos, considerou-se os animais aptos para ini cio do primeiro período do experimento. Nos dojs primeiros períodos do ensaio, praticamente não ocorreram sobras de alimentos. A partir do terceiro período, entretanto, dois dos animais passaram a recusar a mistura semente de maracujä/torta de algodão que deveriam receber nas proporções de 200/ $100 \mathrm{~g}$ e 300/100g, respectivamente.

A recusa inicial do alimento provavelmente se deveu $\grave{a}$ falta de hábito dos animais com o mesmo (SCHNEIDER e FLATT, 1975); uma baixa palatibilidade da semente de maracujá para os animais experimentais é também uma explicação plausivel vez que quanco adicionou-se a torta de aigodão, altamente palatavel à carneiros (PEIXOTO, 1979, comunicação pessoal), o consumo da mistura imediatamente foi aumentada.

A rejeição da semente de maracujá mais torta de algodão ob servada no terceiro e quarto períodos ocorreu nos animais que recebiam 200 e $300 \mathrm{~g}$ de semente de maracujá o que elevava o teor de extrato etéreo da ra ção para 7,45 e 10,04\%, na matéria seca, respectivariente. O nível de extrą to etéreo recomendado para rações de ruminantes é por volta de 6\%̈ (CRAPP- 
PTON e HARRIS, 1969) e um dos problemas associados a niveis mais altos é justamente queda no consumo de alimentos (KOWALCZYK et ali1, 1977). Dessa forma, provavelmente a recusa da porção de ração contendo semente de maracujá, por dois dos animais, está relacionada com seu teor de graxa.

O consumo diário de matéria seca pelos carneiros usados no experimento, cujo peso médio era de $55 \mathrm{~kg}$, deveria ser de $1700 \mathrm{~g}$ segundo ANDRIGUETTO et alii (1978). No ensaio as rações não foram oferecidas à von tade e sim foram baseadas em cerca de $90 \%$ do consumo obtido pelos animais na fase pré-experimental, o que representou, durante o experimento, $700 \mathrm{~g}$ de matéria seca/dia, conforme quadro 7, bem abaixo do previsto por ANDRIGUETTO et alii (1978). SOBRAL (1976), trabalhando com carreiros submetidos a três rações, uma constituida de feno, e as demais de feno mais dois níveis de farelo de coco, coteve um consumo de $620 \mathrm{~g} / \mathrm{animal} / \mathrm{dia}$ e atribuiu tal resultado a baixa qualidade do feno. No presente experimento o feno utilizado, de média a baixa qualidade, era a porção da ração selecionada e parcialmente rejeitada pelos animais, sendo, portanto, considerado o fator limitante do consumo.

Mesmo com o consumo da matéria seca abaixo do indicado por ANDRIGUETTO et alii (1978), a dieta supriu as necessidades de manutenção dos carneiros, Tal conclusão baseia-se na pequena variação de peso dos ani mais entre o início e término do trabalho, conforme pode ser observado no quadro 8. 
Quadro 7. Consumo de alimento, em gramas de matéria seca, por tratamento e por animal/dia.

\begin{tabular}{lcc}
\hline \multirow{2}{*}{ Tratamento } & \multicolumn{2}{c}{ Matéria seca consumida } \\
\cline { 2 - 3 } & $\mathrm{g} /$ tratamento & $\mathrm{g} /$ carneiro/dia \\
\hline $\mathrm{A}$ & 35.795 & 639 \\
$\mathrm{~B}$ & 40.196 & 718 \\
$\mathrm{C}$ & 40.719 & 727 \\
$\mathrm{D}$ & 39.997 & 714 \\
\hline
\end{tabular}

Quadro 8. Variação de peso dos animais $(\mathrm{kg})$ entre o início e o final do experimento.

\begin{tabular}{lcccccccc}
\hline \multirow{2}{*}{ Pesagens } & \multicolumn{7}{c}{ Carneiros } \\
\cline { 2 - 8 } & 1 & 2 & 3 & 4 & 5 & 6 & 7 & 8 \\
\hline Inicial & 57,6 & 48,9 & 56,0 & 52,2 & 60,0 & 49,6 & 58,0 & 60,2 \\
Final & 58,0 & 47,0 & 55,4 & 51,4 & 58,0 & 49,8 & 57,8 & 59,4 \\
& & & & & & & & \\
\hline \multirow{2}{*}{ Variação } & $+0,4$ & $-1,9$ & $-0,6$ & $-0,8$ & $-2,0$ & $+0,2$ & $-0,2$ & $-0,8$
\end{tabular}

5.1. Digestibilidade da dieta total

Os coeficientes de digestibilidade da matéria seca da dieta total e dos seus componentes, encontram-se no quadro 9. A digestibilida de da matéria seca da dieta básica $(62,17 \%)$ aparentemente não foi afetada pela adição de $\log$ de semente de maracujá. Todavia quando 200 ou 300 g da- 
quela semente foram ingeridas pelos animais, houve uma depressão significativa e crescente da digestibilidade da matéria seca total da dieta, cujos valores passaram a ser 56,12\% e 51,97\%, respectivamente. O quadro 4 , onde se encontra a composição quỉmica média da ração em cada um dos tratamentos, mostra a elevação progressiva do extrato etéreo da ração a medida que se aumenta a participação da semente de maracujá na dieta, passando de 2,19\% na ração básica, para $10,04 \%$ no nível mais alto da semente. A elevação do nível de extrato etéreo da dieta tem sido associada a depressão da digestibilidade da fibra bruta e da matéria seca (KOWALCZYK et alii, 1977; SCHNIIDER e FIATT, 1975). De fato, também neste experimento (quadro 9) observou-se uma diminuição significativa da digestibilidade da fibra bruta, de $69,11 \%$ no tratamento A para $32,9 \%$ no tratamento $D$, a medida que se aumentou o nível de semente de maracujá na dieta, depressão aquela que se re fletiu nos coeficientes de digestibilidade da matéria seca.

Quadro 9. Digestibilidade (\%) dos nutrientes da dieta total, de acordo com o nível de semente de maracujá na ração.

\begin{tabular}{|c|c|c|c|c|}
\hline \multirow[t]{2}{*}{ Nutriente $*$} & \multicolumn{4}{|c|}{ Nível de semente de maracujä na racão (g) } \\
\hline & zero & 100 & 200 & 300 \\
\hline Matéria seca & $62,17^{a}$ & $61,35^{2}$ & $56,12^{\mathrm{b}}$ & $51,97^{c}$ \\
\hline Proteina bruta & $64,83^{a}$ & $69,02^{b}$ & $71,47^{b 0}$ & $72,27^{c d}$ \\
\hline Extrato etéreo & $44.49^{2}$ & $76,41^{b}$ & $79,57^{\mathrm{D}}$ & $76,64^{b}$ \\
\hline Fibra bruta & $69,11^{a}$ & $58,68^{b}$ & $45.74^{c}$ & $32,61^{d}$ \\
\hline Extrativo-não-nitrogenado & $62,58^{a}$ & $63.53^{2 c}$ & $58,13^{\mathrm{ac}}$ & $56,37^{c}$ \\
\hline Matéria orgânica & $64,64^{a}$ & $63.27^{2}$ & $57.40^{\mathrm{b}}$ & $53.03^{c}$ \\
\hline
\end{tabular}


Os coeficientes de digestibilidade da matéria orgânica da dieta total (quadro 9) tiveram um comportamento idêntico ao daqueles da matéria seca e se explicam de forma semelhante que para os primeiros.

A digestibilidade da proteina bruta aumentou significativa mente, de $64,83 \%$ no tratamento para $72,27 \%$ no tratamento $D$ com a elevação do nível de semente de maracujá na dieta (quadro 9). Tal fato pode ter sido determinado pela elevação do teor protêico na dieta total de 10,5 para 13,0\%. RAVEN et alii (1969) observaram um decréscimo na digestibilidade da proteina por novilhos, quando o nível daquele nutriente foi menor que 15\% na dieta. BRUCKENTAL et alii (1976), trabalhando com vacas em lactação, observaram também uma queda na digestibilidade da proteina bruta quando es ta passou de 14,6 para $8,5 \%$ da dieta. TAGARI e BEN-GHEDALIA (1977) estudaram a digestibilidade de oito amostras de capim Rhodes que representavam cortes feitos a intervalos de vinte e um dias e que eram preservadas a $-18^{\circ} \mathrm{C}$. O teor de proteina das amostras variou de 10,1 a $14,3 \%$ e sua digestibilidade por carneiros aumentou significativamente de 59,8 para $73,2 \%$, quando a proteina foi elevada como citado anteriormente.

Um segundo fator que contribuiu para a digestibilidade crescente da proteina total, com a elevação do nível de semente de maracu já na dieta é a elevada digestibilidade da proteina desta última, que variou de $93,7 \%$, no tratamento $B$ a $84,2 \%$, no tratamento $D$, conforme o quadro 10.

De acordo com os dados do quadro 9 , tanbém a digestibilide: de do extrato etéreo da dieta total foi significativamente alterada com a adição de semente de maracujá à dieta básica. O coeficiente de digestibili 
de da fração referida, passou de $44,5 \%$ na dieta básica para $76,6 \%$ no tratamento $D$, não sendo detectadas diferenças entre os três níveis de semente, entre si. A diferença de digestibilidade do extrato etéreo em favor dos tratamentos que continham semente de maracujá pode ser atribuida ìs variações de composição daquela fração. Quando proveniente de sementes, a fração extrato etéreo é mais digestivel que a originária de forragens. (SCHNEIDER E FIATT, 1975).

Quadro 10. Digestibilidade $(\%)$ dos nutrientes da semente de maracujá, de acordo com o nível de ingestão.

\begin{tabular}{lccc}
\hline Nutrientes $^{*}$ & \multicolumn{3}{c}{ Nível de ingestão (g) $^{n}$} \\
\cline { 2 - 4 } & $55,95^{\mathrm{a}}$ & $38,89^{\mathrm{b}}$ & 300 \\
\hline Matéria seca & $93,65^{\mathrm{a}}$ & $89,56^{\mathrm{a}}$ & $84,17^{\mathrm{a}}$ \\
Proteina bruta & $93,98^{\mathrm{a}}$ & $89,02^{\mathrm{a}}$ & $81,13^{\mathrm{b}}$ \\
Extrato etéreo & $-2,01^{\mathrm{a}}$ & $-14,00^{\mathrm{a}}$ & $-15,50^{\mathrm{a}}$ \\
Fibra bruta & $74,54^{\mathrm{a}}$ & $32,97^{\mathrm{a}}$ & $36,16^{\mathrm{b}}$ \\
Extrativo-não-nitrogenado & $54,68^{\mathrm{a}}$ & $38,18^{\mathrm{b}}$ & $35,84^{\mathrm{b}}$ \\
Matéria orgânica & & & \\
\hline
\end{tabular}

* Os valores da mesma linha com letras iguais não diferem significativamen te entre si.

Um segundo e importante fator determinante da variação no valor dos indices de digestibilidade encontrados pode ter sido a excre relativamente maior de extrato etéreo endógeno quando os animais recebiam apenas dieta básica (CRAPPTON e HARRIS, 1969). 
Os coeficientes de digestibilidade do extrativo-não-nitrogenado da dieta total (quadro 9) diminuiram significativamente de 62,58\% na dieta básica para $56,37 \%$ no tratamento $D$, com a elevação do nível de semente de maracujá na ração, o que, por sua vez determinou uma relação do teor da fração discutida, de 46,6\% na dieta básica, para 37,4\% no tratamen to que continha $300 \mathrm{~g}$ de semente de maracujá. A redução concomitante do teor de extrativo-não-nitrogenado na dieta e da digestibilidade daquela fração, tem sido encontrada por autores como SUDWEEKS (1976 e 1977) e STONE e FONTENOT (1965), e é atribuida por ANNISON e IEWIS (1969) citados por STONE e FONTENOT (1965), ao menor desenvolvimento de microorganismos do ru men, responsáveis pela fermentação de carboidratos solúveis, nas circunstâncias discutidas.

\subsection{Digestibilidade da semente de maracujá}

Os coeficientes de digestibilidade da semente de maracujá encontram-se no quadro 10. A elevação do nível de ingestão daquele alimento de $100 \mathrm{~g} /$ dia no tratamento $\mathrm{B}$, para 200 ou $300 \mathrm{~g} / \mathrm{dia}$, nos tratamentos C e $\mathrm{I}$, respectivamente, determinou uma depressão estatisticamente significativa, na digestibilidade da matéria seca, que passou de 55,9\% para 36,0\%. Tal de pressão reflete a diminuição de digestibilidade de todos os componentes da matéria seca da semente de maracujá com excessão da proteina e fibra bruta.

Através do uso de regressão, calculou-se a reta que expres sa a relação entre nível de semente de maracujá na dieta e digestibilidade de sua matéria seca (figura 1) que representa a equação $y=63,5608-0,0997 x$, onde $x$ é a quantidade de semente de maracujá na dieta e $y$, a digestibilide 


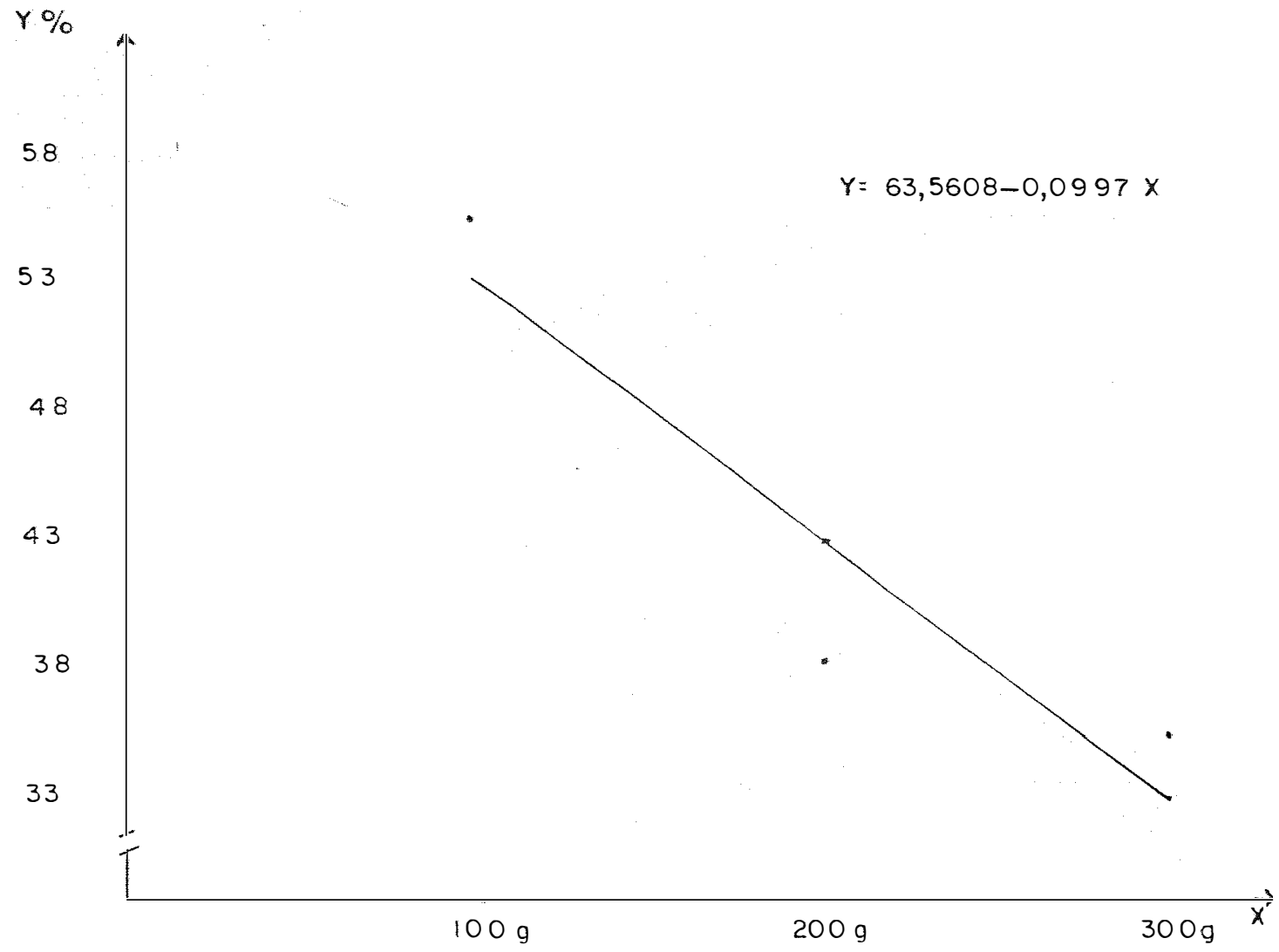

FIG.1 relacâo entre quantidade de semente de mạacujá(x) inaerida e diaestibilidade $\%(y)$ de sua matéria seca $\left(R^{2}=85,59\right)$ 
de de sua matéria seca.

A digestibilidade da fibra bruta da semente de maracujá não diferiu estatisticamente entre os três tratamentos adotados. Seus valo res calculados foram sempre negativos e tal fato reflete uma possível faIha do método de determinação da digestibilidade "por diferença". Neste mé todo a digestibilidade do alimento interesse é calculada pela diferença en tre a digestibilidade total da ração e a digestibilidade de sua fração cor respondente à dieta básica, considerando-se a digestibilidade das frações da dieta básica como constantes. Sabe-se, porém, que tal constância nem sempre ocorre e no caso em discussão, conforme já comentado anteriormente, a elevação do teor de extrato etéreo da dieta total provavelmente reduziu de forma crescente a digestibilidade da fibra bruta da dieta básica. Como para o cálculo da digestibilidade da fibra bruta da semente de maracujá a reférida redução, por não ser conhecida, não foi considerada, chegou-se a valores negativos, conforme o quadro 10. Mesmo assim pode-se admitir une digestibilidade verdadeira baixa para a fibra da semente de maracujá, con base em seu elevado teor de cutina, em torno de 41,8\% na matéria seca, con forme o quadro 3. VAN SOEST e ROBERTSON (1976) afirmam que na cutícula das sementes, a cutina associada à lignina é um fator importante na diminuição da digestibilidade da fráção fibrosa da semente como um todo.

A digestibilidade da proteina da semente de maracujá foi elevada, e sua variação foi de $93,7 \%$ no tratamento $B$ para $84,2 \%$ no tratamento $D$, sem que fossem constatadas diferenças estatisticamente significativas entre os tratamentos. Um coeficiente de variação de $14,4 \%$ para os dä dos de digestibilidade da proteina da semente de maracujá, considerado mé- 
dio por PIMENTEL GOMES (1973), indica a precisão dos resultados obtidos.

A digestibilidade da matéria orgânica da semente de maracu já teve comportamento semelhante a encontrada para a matéria seca desse alimento e seu valor encontra-se no quadro 10.

Através do uso de regressão calculou-se a reta que expressa a relação entre nível de semente de maracujá na dieta e digestibilidade de sua matéria orgânica (figura 2)., que representa a equação y $=61,7395-$ $0,0942 x$, onde $x$ é a quantidade de semente de maracujá na dieta e y a diges tibilidade de sua matéria orgânica.

A elevação do nível de semente de maracujá na ração deprimiu de forma significativa a digestibilidade do extrato etéreo do referido ingrediente (quadro 10), que passou de aproximadamente $94,0 \%$ para $81,1 \%$. PALMQUIST e CONRAD (1978) avaliaram a digestibilidade verdadeira, por vacas, de duas rações com níveis de $5,1 \%$ e $10,7 \%$ de extrato etéreo. Foram ob tidos coeficientes de digestibilidade para a fração em análise, de $81 \%$ e $56 \%$, respectivamente. Os autores atribuem tal decréscimo à superação dos limites fisiológicos de aproveitamento de graxas pelos ruminantes, em função do volume de secreções hepáticas e pancreáticas, no nível mais elevado do extrato etéreo da dieta estudada. No presente trabalho os níveis de extrato etéreo variam de 4,8 a $10,0 \%$ nos tratamentos que continham semente de maracujá. Desta forma, a diminuição na digestibilidade da fração discutida foi ocasionada pelos mesmos motivos sugeridos por PAIMQUIST e CON$\operatorname{RAD}(1978)$. 


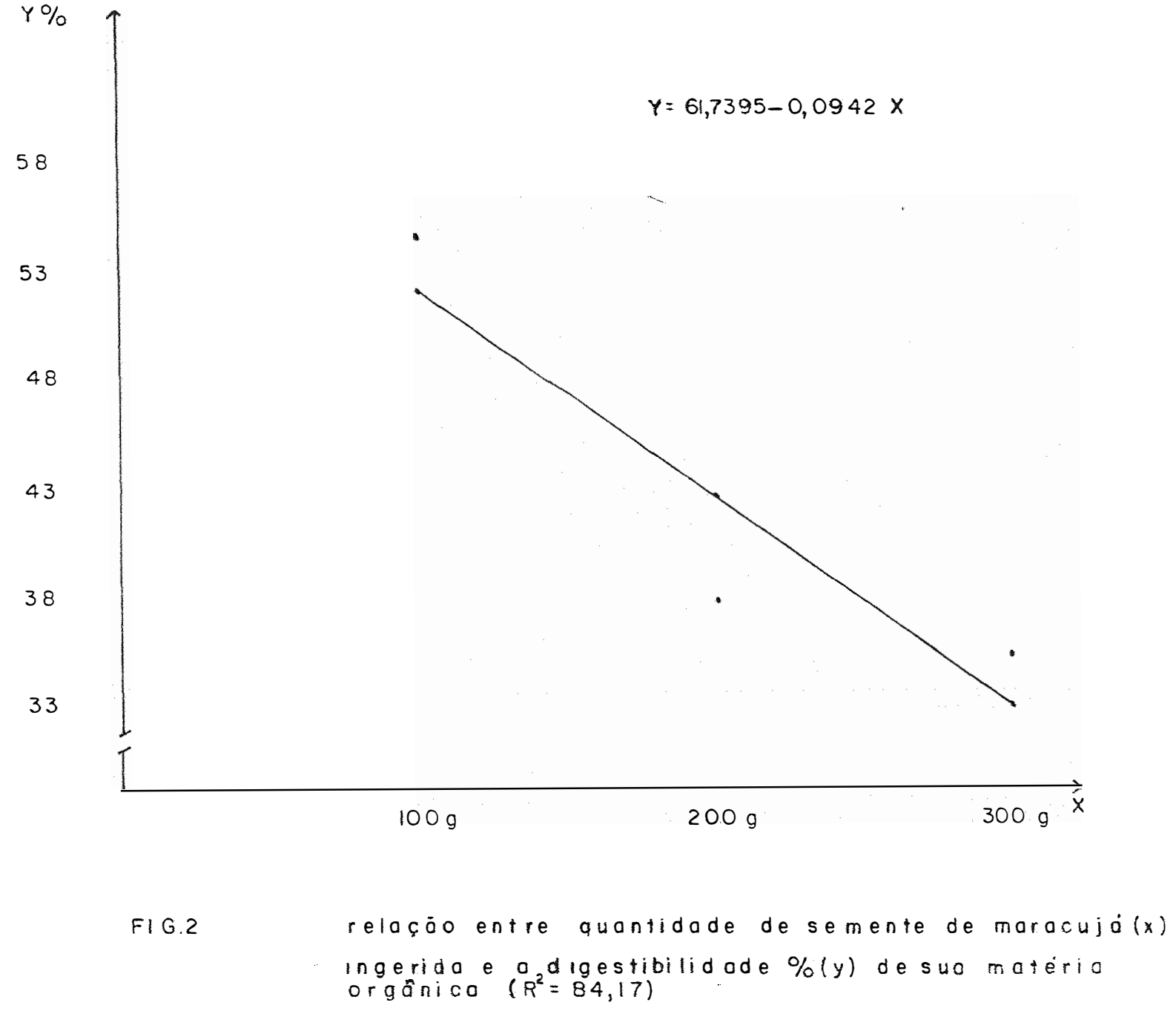


Através do uso da regressão calculou-se a reta que expressa a relação entre nível de semente de maracujá na dieta e digestibilidade de seu extrato etéreo (figura 3) que representa a equação y $=100,8920$ $0,0642 x$, onde $x \ddot{e}$ a quantidade de semente de maracujá na dieta e y a diges tibizidade do seu extrato etéreo.

A digestibilidade da fração extrativo-não-nitrogenado da semente de maracujá diminuiu significativamente, de 74,54\% para 38,18 e $35,84 \%$ (quadro 10) quando a participação desta última na ração foi elevada de $100 \mathrm{~g}$, no tratamento $\mathrm{B}$, para $200 \mathrm{~g}$ ou $300 \mathrm{~g}$, nos tratamentos C e D, respec tivamente. Tal fato reflete, provavelmente, a diminuição do teor de extrativo-não-nitrogenado da dieta total, com a elevação da participação da semente de maracujá na ração, conforme já discutido anteriormente.

Através do uso de regressão calculou-se a reta que expressa a relação entre nível de semente de maracujá na dieta e digestibilidade de seu extrativo-não-nitrogenado (figura 4) que representa a equação $y=86,2761-0,1919$, onde $x \ddot{e}$ a quantidade de semente de maracujá na dieta e y a digestibilidade do seu extrativo-não-nitrogenado. 


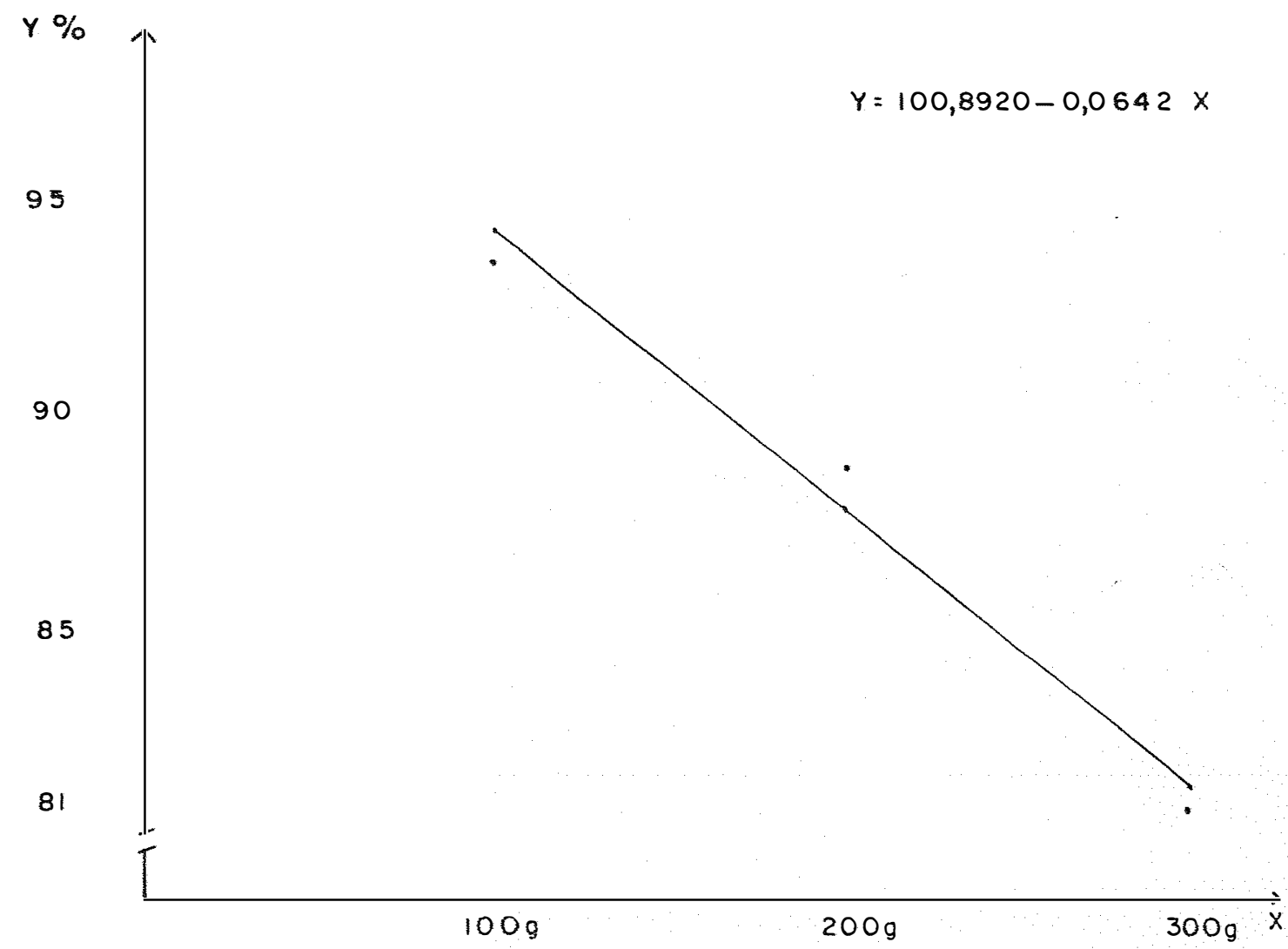

FIG. 3

relacóo entre quontidode de semente de moracuja $(x)$ ingerida e diaestibilidade $(y)$ de seu extrato etéreo $\left(R^{2}=98,28\right)$ 


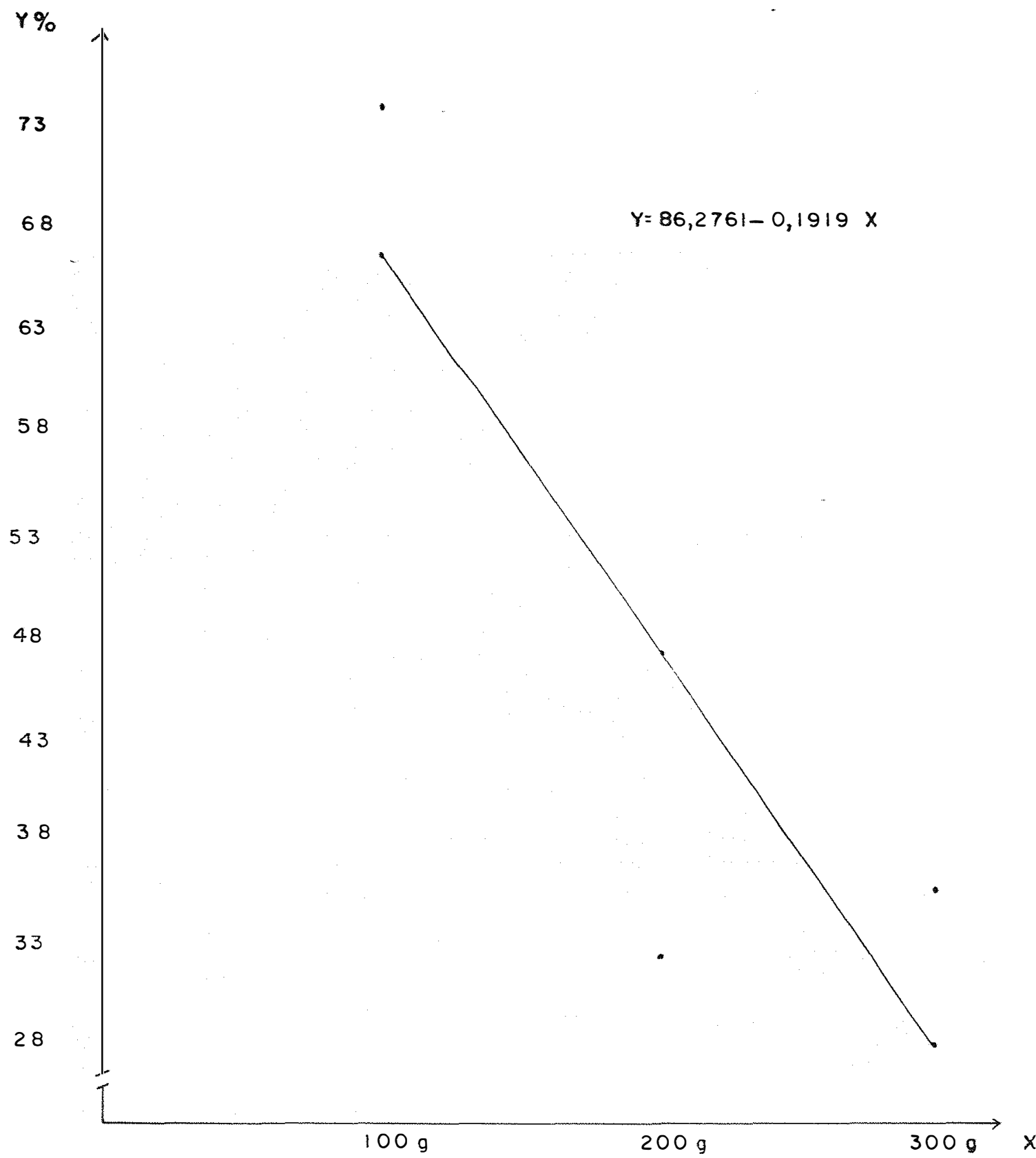

FIG. 4 relaçóo entre a quantidade de semente de maracuja $(x) \operatorname{ng} g$ erida e a digestibilidade \% (y) de seu extrotivo-ndo-nitrogenodo $\left(R^{2}=68,82\right)$ 


\section{CONCLUSOัES}

a) A utilização da semente de maracujá como alimento, por ruminantes é limitada pelo elevado teor de extrato etéreo daquele material.

b) O elevado teor de fibra bruta, basicamente cutina, da semente de maracujá e a associação inversa entre nível desse alimento e a digestibilidade da fibra da dieta total, indicam não ser recomendada a associação na mesma ração, da semente de maracujá e de outros ingredientes com teores elevados de fibra bruta.

c) Não devendo ser usado em níveis elevados na dieta de ru minantes e não sendo adequado para associação a volumosos, a semente de ma racujá não é um bom ingrediente para formulação de rações para polígástri$\cos$.

d) O teor de extrato etéreo da semente de maracujá sugere a possibilidade do seu aproveitamento para produção de óleo. 


\section{SUMMARY}

Eight mature sheep were used in digestibility trials to evaluate the use of Passion fruit seed (Passiflora edulis, Sims. forma flavicarpa, Deuger) as a feed ingredient forruminant rations. The animals were fed a basal ration of Rhodes grass hay (Chloris gayana) and cotton seed meal; the seed replaced 0, 100,200 and $300 \mathrm{~g}$ of hay, respectively, in the four treatments. Total diet dry matter (62.2 to $52.0 \%)$, crude fiber (69.1 to $32.9 \%)$ and nitrogen free extract (N F E) (62.6 to 56.4\%) digestibilities, were lowered, whereas crude protein (64.8 to $77.3 \%)$ and ether extract (E E) (44.5 to $76.6 \%$ ) digestibilities were enhanced by increasing levels of the seed in the diet. The seed dry matter $(56.0$ to 36.0\%), NFE(74.5 to 36.2\%) and $\mathrm{EE}(94.0$ to $81.1 \%)$ digestibilities were lowered, whereas crude protein $(89.1 \%)$ and crude fiber $(-10.5 \%)$ were unchanged by increasing levels of the seed in the diet. The estimated T D N value of the was $64.9 \%$. 


\section{IITERATURA CITADA}

ABOU AKKADA, A.R. e K. EL-SHAZLY. 1958. Studies on the nutritive value of some common egyption feedingstuffs; effect of concentrates rich in proteins on cellulose and dry-mater digestion. The Journal of Apricultural Science, $51(2): 157-63$.

AKIN, D.E.; E.L. ROBINSON; F.E. BARTON II e D.S. HIMMELSBACH. 1977. Changes with naturality in anatomy, histochemistry, chemistry and tissue digestibility of bermudagrass plant parts. Journal of Agxicultural Food Chemistry, 25(1):179-86.

ANDRIGUETTO, J.M.; L.PERLY; A. GEMAEL; I. MINARDI; J.S. FLEMMING; R. FIEMMING e G.A. DE SOUZA. 1978. Normas e padrões de nutrição e alimentação animal. Curitiba. Nutrição Editora e Publicitária LTDA, p. 99-104.

A.O.A.C. (Association of Official Analytical Chemists). 1975. Animal feeá. In: 
ARIKI, J.; C.RUGGIERO; P.R. TOLEDO e J.C. DE OLIVEIRA. 1977. Aproveitamento de cascas desidratadas e sementes de maracujá (Passiflora edulis forma flavicarpa, Geuger) na alimentação de frangos de corte. Científica. Jaboticabal, 5(3):340-3.

ARNOID, G.W. 1966. The special senses in grazing animals; smell, taste, and touch and dietary habits in sheep. Australian Journai of Agricultural Research. East Melbourne, 17:531-42.

BAUMGARDT, B.R. 1970. Control od feed intake in the regulation of energy balance. In: THIRD INTERNATIONAI SYMPOSIUM, Cambridge, 1969. Physiology of digestion and metabolism in the ruminant. Oriel Press, 235-53.

BRUCKEMTAI, I.; S. AMIR; H. TAGARI; D. DRORI; H. NEUMARK e H. KENNIT. 1976. Minimum protein requirements for milking cows. In: SIMPOSIUM ON RECENT DEVEIOPMENTS IN THE USE OF NEW SOURCES OF PROTEIN, ESSENTIAL AMINO ACIDS AND NON-PROTEIN NITROGEN WITH SPECIAL REFERENCE TO RUMINANTS. New York. Food and Agriculture Organization of the United Nations, 248-59.

CIANTON, D.C. 1961. Comparison of $?$ and 10 day collection periods in digestion and metabolism trials with beef heifers. Journal of Animal Science. Albany, $20(3): 640-3$.

CRAMPTON, E.W. E I.E. HARRIS. 1969. Applied animal nutrition; the use of feedstuffs in the formulation of livestock rations. 2 ed. San Francis co, W.H. Freeman and Company. 753p.

DEVENDRA, C. e D. IEWIS. 1974. The interaction between dietary lipids and fibre in the sheep; digestibility studies. Animal Production, 19:67-76. 
ELLIOTT, R.C. e J.H. TOPPS. 1963. Voluntary intake of low protein diets by sheep. Animal Production, 2:269-76.

EL-SHAZLY, K.; B.A.DEHRITY e R.R.JOHNSON. 1961. Effect of stareh on the digestion of cellulose "in vitro" and "in vivo" by rumen microorganisms. Journal of Animal Science. Albany, 20(2):268-73.

GOERING, H.K. e P.J. VAN SOEST. 1970. Forage fiber analysis, agriculture handbook 379. Washington D.C., United States Departament of Agriculture.

GRAHAM, N. Mec.; F.W. WAINMAN, K.L. BLAXTER e D.G. ARMSTRONG• 1959• Environmental temperature, energy metabolism and heat regulation in sheep; energy metabolism in closely clipped sheep. Journal of Agricultural Science. Cambridge, 52:13-24.

GUPTA, B.S.; D.E. JOHNSON e F.C. HINDS. 1978. Soybean straw intake and nutrient digestibility by sheep. Journal of Animal Science. Albany, $46(4): 1086-90$.

HALL, G. e P.G. WOOIFOLK. 1952. Comparison of different lenght preliminary and collection periods in digestion trials with lambs fed chopped alfalfa hay. Journal of Animal Science. Albany, 11:762. (abstract).

HAN, Y.W.; J.S. LEE e A.W. ANDERSON. 1975. Chemical composition and digestibility of ryegrass straw. Journal of Agricultural Food Chemistry, $\underline{23}(5): 928-31$. 
JOHNSTON, M.J. e R. WAITE. 1965. Studies in the lignification of grasses; perennial ryegrass (524) and cocksfoot (537). Journal of Agricultural Science. Cambridge, 64:211-19.

KALIL, E.B. 1977. Principios de técnica experimental com animais. 2 ed. Piracicaba, 210p.

KING, W.A.; J. IEE III; H.J. WEBB e D.B. RODERICK. 1960. Comparison of 6 and 10 day collection periods for digestion trials with dairy heifers. Journal of Dairy Science. Champaign, 43(3):388-92.

KOWALCZYK, J.; E.R. ORSKOV; J.J. ROBINSON e C.S. STEWART. 1977. Effect of fat supplementation on voluntary food intake and rumen metabolism in sheep. Britanic Journal of Nutrition, 32:251-57.

LANDGRAF, J.H. 1978. Industrialização do maracujá. In: SIMPÓSIO SOBRE A CULTURA DO MARACUJÁZEIRO, 2. Jaboticabal, 1978. Anais. Jaboticabal, Carlos Ruggiero. p.9-11.

NORTHCOTE, D.H. 1972. Chemistry of the plant cell wall. Annual Review Plant Physiology, 23:113-32.

PALMQUIST, D.L. e H.R. CONRAD. 1978. High fat rations for dairy cows; effects on feed intake, milk and fat production, and plasma metabolites. Journal of Dairy Science. Champaign, 61:890-901.

PIMENTEL GOMES, F. 1973. Curso de estatística experimental. 5 ed. São Paulo, Livraria Nobel. 448p. 
VAN SOEST, P.J. R.H. WINW. 1967. Use of detergents in the analysis of fibrous feeds, determination of plant cell-wall constituints. Journal of the A.O.A.C., $50(1): 50-5$.

VAN SOEST, P.J. e J.B. ROBERTSON. 1976. Composition and nutritive value of uncommon feedstuffs. In: CORNELI NUTRITION CONFERENCE FOR FEED MANUFACTURERS, Cornel University, Ithaca, 1976. Proceedings. Ithaca, Departament of animal science and poultry science of the New York State College of Agriculture and Life Science. $126 \mathrm{p}$.

WESTON, R.H. 1966. Factors limiting the intake of feed by sluep; the significance of palatibility, the capacity of the alimentary tract to haudle digesta, and the supply of glucogenic substrate. Australian Journal of Agricultural Research, East Melbourne, 12:939-54.

WESTON, R.H. 1967. Factors limiting the intake of feed by sheep; studies with wheaten hay. Australian journal of Agricultural Research, East Melbourne, 18:983-1002.

WHITE, T.W.; F.G. HEMBRY e W.L. REYNOIDS. 1974. Influence of level of dehydrated coastal bermudagrass or rice straw on digestibility. Journal of Animal Science, Albany, 38(4):844-49. 
SOBRAL, J. do P. 1976. Composicão química e digestibilidade do farelo de. côco. Piracicaba, Escola Superior de Agricultura "Iuiz de Queiroz". 62 p. (Tese de Mestrado).

STAPIES, H.J. e W.E. DINUSSON. 1951. A comparison of the relative accura cy between seven-day and ten-day collection periods in digestion trials. Journal of Animal Science. Albany, II(1):244-50.

STONE, P.A. e J.P. FOTENOT. 1965. Effect of available energy level of fattening rations on utilization of nitrogen and digestibility by steers. Journal of Animal Science. Al̦bany, 24:757-60.

SUDWEEKS, E.M. 1976. Influence of tipe and amount of grain on digestibility of rations containing cottouseed hulls. Journal of Dairy Science. Champaign, 59(5):907-11.

TAGARI, H. e D. BEN GHEDAIIA. 1976. The digestibility of Rhodes grass (Chloris gayana) in relation to season and proportion of the diet of sheep. Journal of Agricultural Science. Cambridge, 88:181-5.

TAGARI, H.; D. BEN GHEDAIIA e Y. SHTERN. 1977. The effect of two feeding levels of diets containing field-cured or frozen Rhodes grass (Ghloris gayana), on digestibility and rumen metabolites in sheep. Journal of Agricultural Science. Cambridge, 89:177-82.

TYRRELL, H.F. E P.W. MOE. 1975. Production effeciency in the high producing caw; effect of intake on digestive efficiency. Journal of Dairy Science. Champaign, 58:1151-63. 
RAVEN, A.M.; T.J. FORBES e J.H.D. IRWIN. 1969. The utilization by beef cattle of concentrate diets containing different levels of milled barley straw and of protein. Journal of Agricultural Science. Cambridge, 23: $355-63$.

SCHNEIDER, B.H. e W.P. FLATT. 1975. The avaluation of feeds through digestibility experiments. Athens, University of Georgia Press. 423 p.

SUDWEEKS, E.M. 1976. Influence of type and amount of grain on digestibility of rations containing cottoriseed huls. Journal of Dairy Science. Champaign, 29(5):907-11.

SUDWEEKS, E.M. 1977.' Digestibility by sheep of diets of citrus pulp, corn or soybean mill feed with three forages. Journal of Dairy Science. Champaign, 60(9):1410-15.

SINGH, R•; P.C. GUPTA; K. SINGH e K. PRADHAN. 1976. Studies on the cellwall constituints of important legume and non-legume forages, and their "in vitro" digestibility. Indian Journal of Animal Science, 46(2):80-3.

SJOSTROM, G. e Z.F.I. ROSA. 1978. Estudos sobre as caractertsticas físicas e compksição química do maracujá amarelo (Passiflora edulis forma flacicarpa, Deuger). cultivado no município de Entre Rios, Bahia. In: CONGRESSO BRASIIEIRO DE FRUTICUITURA, 5, Salvador, 1977. Anais. Cruz das Almas, Almir Pinto da Cunha Sobrinho. p 265-73.

SNEDDEN, W.W. 1977. Granadilla (passion fruit) seed from Kenya. Bulletim of Imperial Institute, (35):22-3. (abstract). 
9. APENDICE 
Quadro 11. Total de matéria seca(g) ingerida na fase de coleta, por carneiro e por período.

\begin{tabular}{|c|c|c|c|c|}
\hline \multirow[t]{2}{*}{ Carneiros } & \multicolumn{4}{|c|}{ Períodos } \\
\hline & $I$ & II & III & IV \\
\hline 1 & $5158(D)$ & $5097(C)$ & $5006(A)$ & 5047 (B) \\
\hline 2 & $5114(C)$ & $5044(B)$ & $4088(D)$ & $3550(\mathrm{~A})$ \\
\hline 3 & $5139(D)$ & $5076(C)$ & $3531(A)$ & 4962 (B) \\
\hline 4 & $5113(C)$ & $5049(B)$ & $5114(\mathrm{D})$ & 3519 (A) \\
\hline 5 & $5107(B)$ & $5016(A)$ & $5098(C)$ & $5116(\mathrm{D})$ \\
\hline 6 & $5107(B)$ & $5040(\mathrm{~A})$ & $5111(C)$ & $5116(D)$ \\
\hline 7 & $5081(\mathrm{~A})$ & 5144 (D) & $5048(B)$ & $5062(C)$ \\
\hline 8 & $5052(A)$ & $5122(D)$ & $4832(B)$ & 5048 (C) \\
\hline
\end{tabular}




\begin{tabular}{|c|c|c|c|c|}
\hline \multirow[t]{2}{*}{ Carneiros } & \multicolumn{4}{|c|}{ Períodos } \\
\hline & I & II & III & IV \\
\hline 1 & $2280(\mathrm{D})$ & $2304(C)$ & $1788(\mathrm{~A})$ & $1805(\mathrm{~B})$ \\
\hline 2 & $2414(C)$ & $2052(B)$ & $1946(D)$ & $1565(\mathrm{~A})$ \\
\hline 3 & 2547 (D) & $2385(C)$ & $1336(\mathrm{~A})$ & 1799 (B) \\
\hline 4 & $2264(C)$ & $1996(B)$ & $2533(D)$ & $1381(\mathrm{~A})$ \\
\hline 5 & $1980(\mathrm{~B})$ & $1812(\mathrm{~A})$ & $2192(C)$ & $2397(\mathrm{D})$ \\
\hline 6 & 2091 (B) & $1871(\mathrm{~A})$ & $2008(C)$ & $2357(D)$ \\
\hline 7 & $1885(\mathrm{~A})$ & $2681(D)$ & $1936(\mathrm{~B})$ & $2206(C)$ \\
\hline 8 & $1790(\mathrm{~A})$ & $2473(D)$ & $1880(\mathrm{~B})$ & $2094(C)$ \\
\hline
\end{tabular}


Quadro 13. Percentual de nutrientes digestiveis e de nutrientes digestiveis totais (NDT) da semente de maracujā, em três níveis de ingestão.

\begin{tabular}{|c|c|c|c|}
\hline \multirow{2}{*}{$\begin{array}{l}\text { Nutrientes } \\
\text { digestiveis }\end{array}$} & \multicolumn{3}{|c|}{ Nível de ingestão(g) } \\
\hline & 100 & 200 & 300 \\
\hline Proteina & 11,41 & 10,91 & 10,25 \\
\hline Extrato etéreo x 2,25 & 45,74 & 43,34 & 39,49 \\
\hline Fibra* & 0,0 & 0,0 & 0,0 \\
\hline Extrativo-não-nitrogenado & 17,38 & 7,69 & 8,43 \\
\hline $\mathrm{NDT}$ & 74,53 & 61,94 & 58,17 \\
\hline
\end{tabular}


Quadro 14. Peso dos carneiros (kg) durante o experimento.

\begin{tabular}{lcccccccc}
\hline \multirow{2}{*}{ Pesagens } & \multicolumn{7}{c}{ Carneiros } \\
\cline { 2 - 9 } & 1 & 2 & 3 & 4 & 5 & 6 & 7 & 8 \\
\hline Inicial (14-01-78) & 60,6 & 50,4 & 56,6 & 55,6 & 60,8 & 51,6 & 60,6 & 61,2
\end{tabular}

Período I-coleta

$\begin{array}{llllllll}\text { Inicial(21-01-79) } 57,6 \quad 48,9 & 56,0 & 52,2 & 60,0 & 49,6 & 58,0 & 60,2\end{array}$

Final $\quad(28-01-79) \quad 56,8 \quad 49,4 \quad 56,6 \quad 52,4 \quad 57,2 \quad 50,0 \quad 57,8 \quad 61,6$

Período II-coleta

Inicial(04-02-79) $57,2 \quad 49,0 \quad 56,4 \quad 52,8 \quad 60,0 \quad 51,4 \quad 57,6 \quad 59,6$

Final $\quad(11-02-79) \quad 56,9 \quad 49,6 \quad 56,0 \quad 52,8 \quad 58,6 \quad 49,6 \quad 57,4 \quad 59,4$

Período III-coleta

$\begin{array}{llllllll}\text { Inicial(11-03-79) } 57,7 \quad 47,4 & 54,4 & 52,6 & 59,0 & 48,7 & 58,6 & 61,2\end{array}$

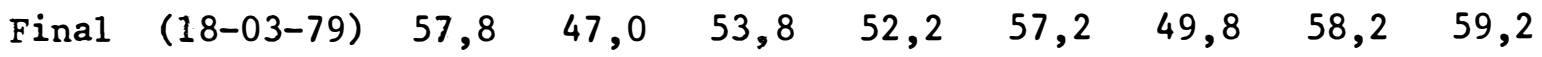

Período IV-coleta

$\begin{array}{llllllll}\text { Inicial(25-03-79) } \quad 56,8 \quad 48,8 \quad 54,8 & 52,4 & 57,0 & 49,0 & 57,8 & 59,0\end{array}$

Final (01-04-79) $\quad 58,0 \quad 47,0 \quad 55,4 \quad 51,4 \quad 58,0 \quad 49,8 \quad 57,8 \quad 59,4$ 
Quadro 15. Coeficiente de digestibilidade da matéria seca total da dieta*.

\begin{tabular}{|c|c|c|c|c|}
\hline & & \multicolumn{3}{|c|}{ Quadrado Latino 1} \\
\hline Períodos Cameiros & 8 & 1 & 4 & 6 \\
\hline$I$ & $64,58(A)$ & $55,80(D)$ & $55,72(C)$ & 59,05 (B) \\
\hline II & $51,72(D)$ & $54,79(C)$ & $60,47(B)$ & $62,87(A)$ \\
\hline III & $61,09(\mathrm{~B})$ & $64,29(A)$ & $50,46(D)$ & $60,71(\mathrm{C})$ \\
\hline \multirow[t]{2}{*}{ IV } & $58,52(C)$ & $64,23(B)$ & $60,76(A)$ & $53,92(D)$ \\
\hline & & \multicolumn{3}{|c|}{ Quadrado Latino 2} \\
\hline Períodos Carneiros & 7 & 3 & 2 & 5 \\
\hline I & $62,91(A)$ & $50,45(D)$ & $52,80(C)$ & $61,22(B)$ \\
\hline II & $47,88(D)$ & $53,01(C)$ & $59,33(\mathrm{~B})$ & $64,87(A)$ \\
\hline III & $61,66(B)$ & $62,17(A)$ & $52,39(D)$ & $57,00(C)$ \\
\hline IV & $56,42(C)$ & $63,75(\mathrm{~B})$ & $55,92(A)$ & $53,14(D)$ \\
\hline
\end{tabular}

Médias e respectivos desvios padrão por tratamento

$\overline{\mathrm{x}} \mathrm{A}=67,17 \pm 0,99$

$\overline{\mathrm{x}} \mathrm{B}=61,35 \pm 0,66$

$\overline{\mathrm{x}} \mathrm{C}=56,12 \pm 0,95$

$\overline{\mathrm{x}} \mathrm{D}=51,97 \pm 0,86$

* As letras entre parênteses correspondem aos tratamentos 
Quadro 16. Coeficiente de digestibilidade da matēria seca da semente de maracujā

\begin{tabular}{|c|c|c|c|c|}
\hline \multicolumn{5}{|c|}{ Quadrado Latino 1} \\
\hline Períodos Carneiros & 8 & 1 & 4 & 6 \\
\hline I & $-(A)$ & $42,22(\mathrm{D})$ & $41,27(C)$ & $33,39(\mathrm{~B})$ \\
\hline II & $31,42(D)$ & $27,73(C)$ & $58,54(\mathrm{~B})$ & $-(A)$ \\
\hline III & $39,11(B)$ & $-(A)$ & $34,26(D)$ & $54,54(C)$ \\
\hline IV & $41,30(C)$ & $63,83(\mathrm{~B})$ & $-(A)$ & $39,66(D)$ \\
\hline \multicolumn{5}{|c|}{ Quadrado Latino 2} \\
\hline Períodos Carneiros & 7 & 3 & 2 & 5 \\
\hline I & $-(A)$ & $31,80(D)$ & $43,84(C)$ & $43,41(B)$ \\
\hline II & 23,99 (D) & $27,07(C)$ & $81,89(B)$ & $-(A)$ \\
\hline III & $53,37(B)$ & $-(A)$ & $48,66(D)$ & $37,46(C)$ \\
\hline IV & $37,91(C)$ & $74,07(B)$ & $-(A)$ & $36,04(\mathrm{D})$ \\
\hline
\end{tabular}

Médias e respectivos desvios padrão por tratamento

$$
\begin{aligned}
& \bar{x} A=- \\
& \bar{x} B=55,95 \pm 6,02 \\
& \bar{x} C=38,89 \pm 3,13 \\
& \bar{x} D=36,01 \pm 2,67 \\
& \text { *As letras entre parênteses correspondem aos tratamentos }
\end{aligned}
$$


Quadro 17. Coeficiente de digestibilidade da matéria orgânica total da dieta*.

\begin{tabular}{|c|c|c|c|c|}
\hline \multicolumn{5}{|c|}{ Quadrado Latino 1} \\
\hline Períodos Carneiros & 8 & 1 & 4 & 6 \\
\hline I & $66,71(A)$ & $57,12(D)$ & $56,54(C)$ & $60,71(B)$ \\
\hline II & $52,82(D)$ & $56,22(C)$ & $62,14(\mathrm{~B})$ & $65,23(A)$ \\
\hline III & $63,43(B)$ & $67,13(\mathrm{~A})$ & $51,59(D)$ & $62,45(C)$ \\
\hline IV & $59,84(C)$ & $65,98(B)$ & $63,10(A)$ & $54,61(D)$ \\
\hline \multicolumn{5}{|c|}{ Quadrado Latino 2} \\
\hline Períodos Carneiros & 7 & 3 & 2 & 5 \\
\hline I & $65,01(A)$ & $51,42(D)$ & $54,04(C)$ & $63,11(B)$ \\
\hline II & $48,86(D)$ & $54,40(C)$ & $61,38(B)$ & $66,25(A)$ \\
\hline III & $63,83(B)$ & $65,33(A)$ & $53,85(D)$ & $58,69(C)$ \\
\hline IV & $54,74(C)$ & $65,65(B)$ & $58,38(A)$ & $53,91(D)$ \\
\hline
\end{tabular}

Médias e respectivos desvios padrão por tratamento

$$
\begin{aligned}
& \bar{x} A=64,64 \pm 1,00 \\
& \bar{x} B=63,27 \pm 0,73 \\
& \bar{x} C=57,49 \pm 1,00 \\
& \bar{x} D=53,03 \pm 0,87 \\
& * \text { As letras entre parênteses correspondem aos tratamentos }
\end{aligned}
$$


Quadro 18. Coeficiente de digestibilidade da matéria orgânica da semente de maracujā*.

\begin{tabular}{|c|c|c|c|c|}
\hline & & \multicolumn{3}{|c|}{ Quadrado Latino 1} \\
\hline Períodos Carneiros & 8 & 1 & 4 & 6 \\
\hline I & $-(A)$ & $41,97(D)$ & $38,80(C)$ & $32,02(\mathrm{~B})$ \\
\hline II & $31,99(D)$ & $26,71(\mathrm{C})$ & $56,11(B)$ & $-(A)$ \\
\hline III & $43,85(B)$ & $-(A)$ & $34,41(D)$ & $54,93(A)$ \\
\hline \multirow[t]{2}{*}{ IV } & $41,36(C)$ & $58,73(\mathrm{~B})$ & $-(A)$ & $38,55(D)$ \\
\hline & \multicolumn{4}{|c|}{ Quadrado Latino 2} \\
\hline Períodos Carneiros & 7 & 3 & 2 & 5 \\
\hline I & $-(A)$ & $30,75(\mathrm{D})$ & $42,28(C)$ & $43,15(\mathrm{~B})$ \\
\hline II & $24,48(D)$ & $25,00(C)$ & $79,52(\mathrm{~B})$ & $-(A)$ \\
\hline III & $56,39(\mathrm{~B})$ & $-(A)$ & 49,29 (D) & $38,26(\mathrm{C})$ \\
\hline IV & $38,11(C)$ & $67,65(B)$ & $-(A)$ & $35,25(\mathrm{D})$ \\
\hline
\end{tabular}

Médias e respectivos desvios padrão por tratamento

$\overline{\mathrm{x}} \mathrm{A}=-$

$\bar{x} B=54,68 \pm 5,30$

$\bar{x} C=38,18 \pm 3,31$

$\bar{x} D=35,84 \pm 2,67$

* As letras entre parênteses representam os tratamentos 
Quadro 19. Coeficiente de digestibilidade da proteina bruta total da dieta*.

\begin{tabular}{|c|c|c|c|c|}
\hline \multicolumn{5}{|c|}{ Quadrado Latino 1} \\
\hline Períodos Carneiros & 8 & 1 & 4 & 6 \\
\hline I & $67,78(A)$ & $73,73(\mathrm{D})$ & $70,07(\mathrm{C})$ & $68,12(\mathrm{~B})$ \\
\hline II & $70,80(D)$ & $71,97(C)$ & $64,74(B)$ & $62,47(A)$ \\
\hline III & $69,01(B)$ & $65,02(\mathrm{~A})$ & $72,32(\mathrm{D})$ & $71,26(C)$ \\
\hline IV & $73,18(C)$ & $71,57(B)$ & $68,11(\mathrm{~A})$ & $70,77(D)$ \\
\hline \multicolumn{5}{|c|}{ Quadrado Latino 2} \\
\hline Períodos Carneiros & 7 & 3 & 2 & 5 \\
\hline I & $63,60(A)$ & $67,02(D)$ & $70,07(\mathrm{C})$ & $67,36(B)$ \\
\hline II & $72,62(\mathrm{D})$ & $70,22(C)$ & $71,37(B)$ & $66,67(A)$ \\
\hline III & $71,01(\mathrm{~B})$ & $64,44(A)$ & $76,33(\mathrm{D})$ & $72,67(C)$ \\
\hline IV & $72,35(C)$ & $69,04(B)$ & $60,59(A)$ & $74,58(D)$ \\
\hline
\end{tabular}

Médias e respectivos desvios padrão por tratamento

$\bar{x}_{A}=64,83 \pm 0,93$

$\overline{\mathrm{x}} \mathrm{B}=69,02 \pm 0,82$

$\overline{\mathrm{x}} C=71,47 \pm 0,44$

$\overline{\mathrm{x}} \mathrm{D}=72,27 \pm 1,00$

* As letras entre parênteses correspondem aos tratamentos 
Quadro 20. Coeficiente de digestibilidade da proteina bruta da semente de maracujā.

\begin{tabular}{|c|c|c|c|c|}
\hline \multicolumn{5}{|c|}{ Quadrado Latino 1} \\
\hline Períodos Carneiros & 8 & 1 & 4 & 6 \\
\hline I & $-(A)$ & 88,79 (D) & $75,60(C)$ & $102,88(\mathrm{~B})$ \\
\hline II & $75,52(D)$ & $89,00(\mathrm{C})$ & $46,88(B)$ & $-(A)$ \\
\hline III & $75,69(B)$ & $-(A)$ & $78,96(D)$ & $95,28(\mathrm{C})$ \\
\hline IV & $89,07(C)$ & $113,58(\mathrm{~B})$ & $-(A)$ & $85,73(\mathrm{D})$ \\
\hline \multicolumn{5}{|c|}{ Quadrado Latino 2} \\
\hline Períodos Carneiros & 7 & 3 & 2 & 5 \\
\hline I & $-(A)$ & $71,47(D)$ & $96,89(C)$ & $71,35(\mathrm{~B})$ \\
\hline II & $86,19(D)$ & $84,33(C)$ & $128,39(\mathrm{~B})$ & $-(A)$ \\
\hline III & 112,20 (B) & $-(A)$ & $97,86(D)$ & $88,16(C)$ \\
\hline IV & $98,13(C)$ & $98,26(\mathrm{~B})$ & $-(A)$ & $88,18(D)$ \\
\hline
\end{tabular}

Médias e respectivos desvios padrão por tratamento

$\bar{x} A=64,83 \pm 0,93$
$\bar{x} B=93,65 \pm 9,51$
$\bar{x} C=89,56 \pm 2,62$
$\bar{x} D=84,17 \pm 2,99$

* As letras entre parênteses correspondem aos tratamentos 
Quadro 21. Coeficiente de digestibilidade do extrato etéreo total da dieta*.

\begin{tabular}{|c|c|c|c|c|}
\hline & & \multicolumn{3}{|c|}{ Quadrado Latino 1} \\
\hline Períodos Carneiros & 8 & 1 & 4 & 6 \\
\hline I & $41,26(A)$ & $84,54(D)$ & $82,29(C)$ & $72,22(\mathrm{~B})$ \\
\hline II & 77,51 (D) & $83,61(\mathrm{C})$ & $80,16(B)$ & $40,18(A)$ \\
\hline III & $73,07(\mathrm{~B})$ & $53,71(\mathrm{~A})$ & $80,23(\mathrm{D})$ & 75,74 (C) \\
\hline \multirow[t]{2}{*}{ IV } & $76,67(C)$ & $77,35(\mathrm{~B})$ & $47,92(A)$ & $59,52(\mathrm{D})$ \\
\hline & & \multicolumn{3}{|c|}{ Quadrado Latino 2} \\
\hline Períodos Carneiros & 7 & 3 & 2 & 5 \\
\hline I & $41,49(\mathrm{~A})$ & $78,30(\mathrm{D})$ & $78,18(C)$ & $75,23(\mathrm{~B})$ \\
\hline II & $81,34(D)$ & $81,92(\mathrm{C})$ & $80,90(\mathrm{~B})$ & $44,58(A)$ \\
\hline III & $75,93(\mathrm{~B})$ & $47,00(\mathrm{~A})$ & $74,23(D)$ & $80,73(C)$ \\
\hline IV & $77,45(C)$ & $76,40(\mathrm{~B})$ & $39,76(\mathrm{~A})$ & $77,48(D)$ \\
\hline
\end{tabular}

Médias e respectivos desvios padrão por tratamento

$\bar{x} A=44,49 \pm 1,71$

$\bar{x} B=76,11 \pm 1,08$

$\bar{x} c=79,57 \pm 1,04$

$\bar{x} D=76,64 \pm 2,67$

* As letras entre parênteses correspondem aos tratamentos 
Quadro 22. Coeficiente de digestibilidade do extrato etéreo da semente de maracujāt.

\begin{tabular}{|c|c|c|c|c|}
\hline \multicolumn{5}{|c|}{ Quadrado Latino 1} \\
\hline Períodos Carneiros & 8 & 1 & 4 & 6 \\
\hline I & $-(A)$ & $89,95(D)$ & $88,39(C)$ & $98,17(B)$ \\
\hline II & $82,35(D)$ & $92,53(\mathrm{C})$ & $92,38(B)$ & $-(A)$ \\
\hline III & $93,78(B)$ & $-(A)$ & $83,58(D)$ & $89,02(C)$ \\
\hline IV & $87,17(C)$ & $98,78(\mathrm{~B})$ & $-(A)$ & $64,32(D)$ \\
\hline \multicolumn{5}{|c|}{ Quadrado Latino 2} \\
\hline Periodos Cameiros & 7 & 3 & 2 & 5 \\
\hline I & $-(A)$ & $81,39(D)$ & $85,00(C)$ & $99,65(B)$ \\
\hline II & $86,74(D)$ & $87,95(C)$ & $79,53(B)$ & $-(A)$ \\
\hline III & $99,82(\mathrm{~B})$ & $-(A)$ & $76,47(D)$ & $93,82(C)$ \\
\hline IV & $88,26(C)$ & $89,70(B)$ & $-(A)$ & $84,30(D)$ \\
\hline
\end{tabular}

Médias e respectivos desvios padrão por tratamento

$\bar{x} A=-$

$\bar{x} B=93,98 \pm 2,45$

$\bar{x} C=89,02 \pm 1,01$

$\overline{\mathrm{x}} \mathrm{D}=81,13 \pm 2,77$

* As letras entre parênteses correspondem aos tratamentos 
Quadro 23. Coeficiente de digestibilidade da fibra bruta total da dieta*.

\begin{tabular}{|c|c|c|c|c|}
\hline & & \multicolumn{3}{|c|}{ Quadrado Latino 1} \\
\hline Períodos Carneiros & 8 & 1 & 4 & 6 \\
\hline$I$ & $71,83(\mathrm{~A})$ & $41,66(D)$ & $47,94(C)$ & $56,50(B)$ \\
\hline II & $30,26(D)$ & $40,13(C)$ & $56,62(\mathrm{~B})$ & $70,29(\mathrm{~A})$ \\
\hline III & $61,71(\mathrm{~B})$ & $72,95(\mathrm{~A})$ & $26,12(D)$ & $51,45(\mathrm{C})$ \\
\hline \multirow[t]{2}{*}{ IV } & $48,37(C)$ & $62,85(\mathrm{~B})$ & $69,11(\mathrm{~A})$ & $37,88(D)$ \\
\hline & \multicolumn{4}{|c|}{ Quadrado Latino 2} \\
\hline Períodos Carneiros & 7 & 3 & 2 & 5 \\
\hline I & $67,77(A)$ & 40,41 (D) & $46,55(C)$ & $57,20(\mathrm{~B})$ \\
\hline II & $20,48(D)$ & $38,50(C)$ & $54,97(B)$ & $68,98(A)$ \\
\hline III & $57,83(\mathrm{~B})$ & $71,45(\mathrm{~A})$ & $30,24(D)$ & $45,12(\mathrm{C})$ \\
\hline IV & $47,88(C)$ & $61,74(B)$ & $60,50(A)$ & $36,27(D)$ \\
\hline
\end{tabular}

Médias e respectivos desvios padrão por tratamento

$$
\begin{aligned}
& \bar{x} A=69,11 \pm 1,37 \\
& \bar{x} B=58,68 \pm 1,05 \\
& \bar{x} C=45,74 \pm 1,55 \\
& \bar{x} D=32,92 \pm 2,62
\end{aligned}
$$

* As letras entre parênteses correspondem aos tratamentos 
Quadro 24. Coeficiente de digestibilidade da fibra bruta da semente de mara$\operatorname{cujä}$

\begin{tabular}{|c|c|c|c|c|}
\hline \multicolumn{5}{|c|}{ Quadrado Latino 1} \\
\hline Períodos Carneiros & 8 & 1 & 4 & 6 \\
\hline$I$ & $-(A)$ & 7,85 (D) & $6,21(C)$ & $-8,14(\mathrm{~B})$ \\
\hline II & $-29,31(D)$ & $-46,43(\mathrm{C})$ & $-21,06(B)$ & $-(A)$ \\
\hline III & $-5,84(B)$ & $-(A)$ & $-43,43(D)$ & $-5,11(C)$ \\
\hline IV & $-9,89(C)$ & $2,98(B)$ & $-(A)$ & $-6,42(D)$ \\
\hline \multicolumn{5}{|c|}{ Quadrado Latino 2} \\
\hline Períodos Cameiros & 7 & 3 & 2 & 5 \\
\hline I & $67,77(A)$ & $6,55(D)$ & $19,04(C)$ & $1,96(B)$ \\
\hline II & $-47,81(D)$ & $-47,86(C)$ & $20,61(B)$ & $68,98(A)$ \\
\hline III & $-12,26(B)$ & $71,45(A)$ & $-2,97(D)$ & $-26,24(C)$ \\
\hline IV & $-1,70(C)$ & $5,64(B)$ & $60,50(A)$ & $-8,45(D)$ \\
\hline
\end{tabular}

Médias e respectivos desvios padrão por tratamento

$$
\begin{aligned}
& \bar{x} A=- \\
& \bar{x} B=-2,01 \pm 4,49 \\
& \bar{x} C=-14,00 \pm 8,55 \\
& \bar{x} D=-15,50 \pm 7,72
\end{aligned}
$$

* As letras entre parênteses correspondem aos tratamentos 
Quadro 25. Coeficiente de digestibilidade do extrativo-não-nitrogenado total da dieta*.

\begin{tabular}{|c|c|c|c|c|}
\hline & \multicolumn{4}{|c|}{ Quadrado Latino 1} \\
\hline Períodos Carneiros & 8 & 1 & 4 & 6 \\
\hline I & $64,63(A)$ & $58,44(\mathrm{D})$ & $54,88(C)$ & $60,58(B)$ \\
\hline II & $57,12(D)$ & $57,76(C)$ & $63,08(\mathrm{~B})$ & $63,77(A)$ \\
\hline III & $62,11(\mathrm{~B})$ & $64,29(A)$ & $56,80(\mathrm{D})$ & $65,46(C)$ \\
\hline \multirow[t]{2}{*}{ IV } & $61,97(C)$ & $65,57(B)$ & $58,42(\mathrm{~A})$ & $62,19(D)$ \\
\hline & \multicolumn{4}{|c|}{ Quadrado Latino 2} \\
\hline Períodos Carneiros & 7 & 3 & 2 & 5 \\
\hline I & $64,57(A)$ & 49,57 (D) & $50,98(C)$ & $64,95(B)$ \\
\hline II & $53,51(D)$ & $55,72(C)$ & $60,63(B)$ & $65,44(A)$ \\
\hline III & $64,89(\mathrm{~B})$ & $62,27(A)$ & $57,34(\mathrm{D})$ & $60,63(C)$ \\
\hline IV & $57,68(C)$ & $66,44(\mathrm{~B})$ & $57,27(A)$ & $56,04(D)$ \\
\hline
\end{tabular}

Médias e respectivos desvios padrão por tratamento

$$
\begin{aligned}
& \bar{x} A=62,58 \pm 1,09 \\
& \bar{x} B=63,53 \pm 0,80 \\
& \bar{x} C=58,18 \pm 1,60 \\
& \bar{x} D=56,38 \pm 1,30
\end{aligned}
$$

* As letras entre parênteses correspondem aos tratamentos 
Quadro 26. Coeficiente de digestibilidade do extrativo-não-nitrogenado da semente de maracujā*.

\begin{tabular}{|c|c|c|c|c|}
\hline \multicolumn{5}{|c|}{ Quadrado Latino 1} \\
\hline Períodos Carneiros & 8 & 1 & 4 & 6 \\
\hline$I$ & $-(A)$ & $36,12(D)$ & $30,47(C)$ & $8,46(\mathrm{~B})$ \\
\hline II & $33,41(D)$ & $20,13(C)$ & $126,09(\mathrm{~B})$ & $-(A)$ \\
\hline III & $38,78(\mathrm{~B})$ & $-(A)$ & $53,12(D)$ & $72,52(\mathrm{C})$ \\
\hline IV & $49,38(c)$ & $79,93(\mathrm{~B})$ & $-(A)$ & $58,03(D)$ \\
\hline \multicolumn{5}{|c|}{ Quadrado Latino 2} \\
\hline Períodos Carneiros & 7 & 3 & 2 & 5 \\
\hline I & $-(A)$ & 1,45 (D) & $7,52(\mathrm{C})$ & $56,98(\mathrm{~B})$ \\
\hline II & $18,33(D)$ & $18,17(\mathrm{C})$ & $105,90(\mathrm{~B})$ & $-(A)$ \\
\hline III & $67,98(\mathrm{~B})$ & - (A) & $57,43(\mathrm{D})$ & $40,57(C)$ \\
\hline IV & $25,01(\mathrm{C})$ & $112,22(B)$ & $-(A)$ & $31,36(D)$ \\
\hline
\end{tabular}

Médias e respectivos desvios padrão por tratamento

$$
\begin{aligned}
& \bar{x} A=- \\
& \bar{x} B=74,54 \pm 14,07 \\
& \bar{x} C=32,97 \pm 7,31 \\
& \bar{x} D=36,16 \pm 7,04
\end{aligned}
$$

* As letras entre parênteses correspondem aos tratamentos 